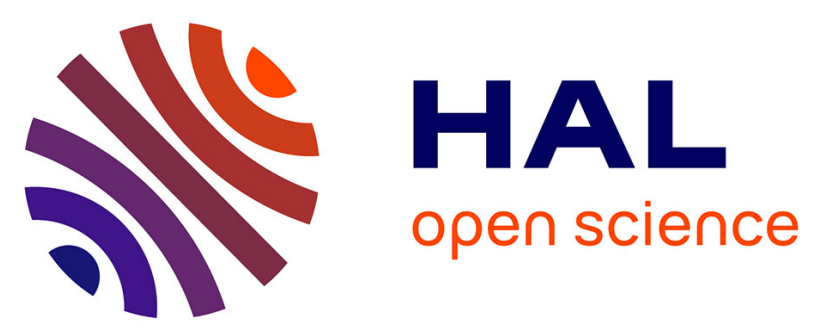

\title{
How to turn off a lava lake? A petrological investigation of the 2018 intra-caldera and submarine eruptions of Ambrym volcano
}

Yves Moussallam, Etienne Médard, Guillaume Georgeais, Estelle Rose-Koga, Kenneth Koga, Bernard Pelletier, Philipson Bani, Tara Shreve, Raphael

Grandin, Marie Boichu, et al.

\section{To cite this version:}

Yves Moussallam, Etienne Médard, Guillaume Georgeais, Estelle Rose-Koga, Kenneth Koga, et al.. How to turn off a lava lake? A petrological investigation of the 2018 intra-caldera and submarine eruptions of Ambrym volcano. Bulletin of Volcanology, 2021, 83 (5), 10.1007/s00445-021-01455-2 . hal-03444016

\author{
HAL Id: hal-03444016 \\ https://hal.science/hal-03444016
}

Submitted on 29 Nov 2021

HAL is a multi-disciplinary open access archive for the deposit and dissemination of scientific research documents, whether they are published or not. The documents may come from teaching and research institutions in France or abroad, or from public or private research centers.
L'archive ouverte pluridisciplinaire HAL, est destinée au dépôt et à la diffusion de documents scientifiques de niveau recherche, publiés ou non, émanant des établissements d'enseignement et de recherche français ou étrangers, des laboratoires publics ou privés. 
1 How to turn off a lava lake? A petrological investigation of the

22018 intra-caldera and submarine eruptions of Ambrym

3 volcano.

4

5 Yves Moussallam ${ }^{1,2 *}$, Etienne Médard ${ }^{3}$, Guillaume Georgeais ${ }^{3}$, Estelle F. Rose-Koga ${ }^{3}$,

6 Kenneth T. Koga ${ }^{3}$, Bernard Pelletier ${ }^{4}$, Philipson Bani ${ }^{3}$, Tara L. Shreve ${ }^{5}$, Raphael

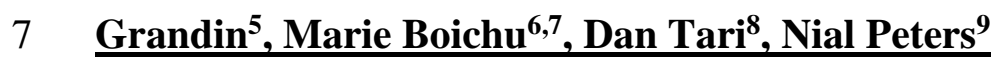

8

$9{ }^{1}$ Lamont-Doherty Earth Observatory, Columbia University, New York, USA

$10 \quad{ }^{2}$ American Museum of Natural History, Department of Earth and Planetary Sciences, NY 10024, New

11 York, USA

$12{ }^{3}$ Université Clermont Auvergne, CNRS, IRD, OPGC, Laboratoire Magmas et Volcans, F-63000

13 Clermont-Ferrand, France

$14{ }^{4}$ Institut de Recherche pour le Développement (IRD), Antenne de Nouméa, Nouvelle Calédonie

$15{ }^{5}$ Institut de Physique du Globe (IPGP), Université de Paris, France

$16{ }^{6}$ Univ. Lille, UMR 8518 - LOA - Laboratoire d'Optique Atmosphérique, F-59000 Lille, France

$17{ }^{7}$ CNRS, UMR 8518, F-59000 Lille, France

$18{ }^{8}$ Vanuatu Meteorology and Geohazards Department (VMGD), Vanuatu

$19{ }^{9}$ University College London, London, United Kingdom

20

21 Corresponding author: Yves Moussallam; yves.moussallam@1deo.columbia.edu

23 Keywords: magma mixing; magma mingling; caldera subsidence; melt inclusion; basaltic 24 eruption; geo-speedometer 
ABSTRACT

27

In December 2018, an unusually large intra- and extra-caldera eruption took place at Ambrym volcano (Vanuatu). The eruption drained the volcano's five active lava lakes and terminated, at least momentarily, the surface activity that had been ongoing for decades to hundreds of years, sustaining the largest recorded persistent degassing on the planet. Here, we investigate the mechanisms and dynamics of this major eruption. We use major elements and volatiles in olivine and clinopyroxene hosted melt inclusions, embayments, crystals and matrix glasses together with clinopyroxene geobarometry as well as olivine and clinopyroxene geothermometry and diffusion modelling in crystals and embayments to reconstruct the chronology and timing of the subsurface processes that accompanied the eruption. We find that the eruption began with the meeting, mingling and limited chemical mixing of mostly two magma bodies occupying similar vertical but different horizontal locations in the crust, one corresponding to the main plumbing system at Ambrym that fed the lava lakes and the other corresponding to an older, previously cut-off and more chemically evolved branch of the plumbing system. Within the primitive magma, two texturally distinct components - one microlite-rich and one microlite-poor - can further be identified. The 2018 eruption hence provides a detailed image of Ambrym's complex plumbing system. Our diffusion timescales and geobarometric estimates coincide closely with geophysical observations. They point to a reconnection of the evolved magmatic branch with the main system occurring less than $10 \mathrm{~h}$ prior to the intra-caldera eruption and a period of two days for the subsequent $>30 \mathrm{~km}$ lateral magma transport along a deeper dike prior to submarine eruption just off the SE coast of the island with the more primitive magma reaching first followed by mingled magma containing both compositions. Magma ascent rates is estimated at $95 \pm 24 \mathrm{~m} / \mathrm{s}$ in the last $\sim 2.5 \mathrm{~km}$ of ascent during the intra-caldera eruption and at $80 \pm 6 \mathrm{~m} / \mathrm{s}$ in the last $\sim 4 \mathrm{~km}$ of ascent during the submarine eruption. Comparison with other lava-lake-draining eruptions reveal striking 
51 similarities both in terms of precursory activity, with lake level rising prior to eruption in all

cases, and in term of plumbing system organisation with the presence of peripheral magma pockets, isolated from the main magmatic system but that can be mobilized and erupted when met by dikes propagating laterally from the main system.

\section{INTRODUCTION}

Lava lakes are the emblem of persistent degassing volcanic activity. They are rare examples of volcanic systems having reached a metastable equilibrium whereby gas and magma motions result in conduit dynamics allowing for efficient gas release whilst maintaining molten magma from the chamber to the surface (e.g., Tazieff 1994; Harris et al. 2005; Witham and Llewellin 2006; Harris 2008; Oppenheimer et al. 2009; Burgi et al. 2014; Moussallam et al. 2015a, 2016; Allard et al. 2016b). As a result, volcanoes with lava lakes tend to rank amongst the major emitters of volcanic gases to the atmosphere - at least for the past decade (Carn et al. 2017) and to maintain surficial activity that can remain nearly unchanged for decades to centuries. In 2018 two of the most iconic lava lake volcanoes, Kîlauea and Ambrym, both experienced major eruptions whereby subsurface magma migration, associated with an episode of caldera collapse, caused the rapid drainage of their lava lakes (Neal et al. 2019; Shreve et al. 2019).

In this study we investigate the mechanism behind the 2018 Ambrym eruption. We present petrological observations of glasses, crystals and melt inclusions of both the initial intra-caldera fire-fountain eruption and subsequent submarine eruption. We then compare these findings to geophysical and surficial observation to derive a detailed understanding of the cause and timing of the eruption as well as the architecture of Ambrym's plumbing system. 

THE 2018 ERUPTION OF AMBRYM VOLCANO

A detailed account of the temporal evolution of the eruption in terms of deformation, seismic, thermal and $\mathrm{SO}_{2}$ gas emissions from ground and satellite observations is given in Shreve et al., (2019). Here we summarise the main events focussing on the deposits and ground observations. We divide the eruption in two parts, the intra-caldera and the submarine eruption.

\section{Intra-caldera eruption}

On 14 December 2018 (all date and time in UTC), the volcano-seismic crisis began with a few events detected inside the caldera. Lava reached the surface around $23 \mathrm{~h} 20$ UTC from two fissures according to high time-resolution thermal observations from Advanced Himawari Imager (AHI) aboard HIMAWARI 8 geostationary satellite (Shreve et al. 2019). Two fissures opened, one trending $\mathrm{N} 110^{\circ}$ at $590 \mathrm{~m}$ a.s.l. and cutting through the Lewolembwi tuff ring (reactivation of a pre-existing fracture) and the other trending N-S at $730 \mathrm{~m}$ a.s.1. and located near the eruption site of the 2015 lava flows. The first fissure produced mainly scoria deposits covering a $1 \mathrm{~km}$ radius (with minor pahoehoe lava flows close to the eruption site) while the second fissure produced a blocky, $10^{6} \mathrm{~m}^{3}$ (Shreve et al. 2019) lava flow (Fig. 1, panel 6, 7 and 8). Both fissures likely resulted in fire fountain style of eruption (visually confirmed only at the second fissure). As lava extrusion proceeded on the SE flank of the volcano during the 15 of December, lava lake activity at the summit ceased according to satellite thermal observations (Shreve et al. 2019). Directly prior to the eruption, five lava lakes were being observed by the authors in the summit region, two at Benbow and three at Marum (with lake level at Marum's main lava lake noticeably increasing in the weeks prior to the eruption; Fig. S1) (Fig. 1, panel 1 and 2). The crater walls around all five lava lakes had partially collapsed inward by 16 December, one lava lake at Marum crater had been replaced by a water lake at that time. A previously vigorously degassing vent located just south of Marum (called Maben Mbwelesu or 
100 Niri Taten, source of the 1988-1989 basaltic lava flow) also ceased degassing (Fig. 1, panel 3).

101 According to HIMAWARI observations, syn-eruptive $\mathrm{SO}_{2}$ degassing mainly took place on 15

102 and 16 December, ceasing early in the morning of 16 December (UT) (Shreve et al. 2019). On

10315 December at 17:45 and 19:45 and on 16 December at 1:00 and 5:00 ash clouds were

104 observed from the Vanuatu Meteorology and Geohazards Department's webcam. On 16

105 December at 3:30, lahars were observed on the flank of both Benbow and Marum (Fig. 1, panel

106 5). Yet no rainfall had been reported since the onset of the eruption, suggesting that the water

107 originated from within the edifices, possibly as a result of compaction during the period of

108 subsidence highlighted by InSAR observations (see next section). By the end of December 16,

109 surficial activity inside the caldera had ceased. Videos from a helicopter overflight in the

110 caldera on 16 December are provided in the supplementary.

\section{Dike propagation and submarine eruption}

113 At $20 \mathrm{~h} 21$ on December 15 the seismic activity increased sharply marking the beginning of 114 magma propagation into the SE rift zone (Shreve et al., 2019). By 17 December at 12:00, 115 inversion of InSAR data revealed $\sim 3 \mathrm{~m}$ of opening along a $>30 \mathrm{~km}$ long dike, of 419 to $116532 \times 10^{\wedge} 6 \mathrm{~m}^{3}$ total volume, dipping $\sim 70^{\circ}$ to the south, and extending from within the caldera

117 to beyond the eastern coast (Shreve et al., 2019). Around 16:00 on December 17 magma 118 migration stopped, likely marking the onset of a shallow submarine eruption just off the SE 119 coast of Ambrym, near the villages of Pamal and Ulei, confirmed in the following days as 120 basaltic pumice drifted to shore. This large magma migration episode in the subsurface was 121 accompanied by inflation in the SE part of the island (Fig 1, panel 4) but also by subsidence 122 (>2 m) of the caldera floor (Shreve et al., 2019). 

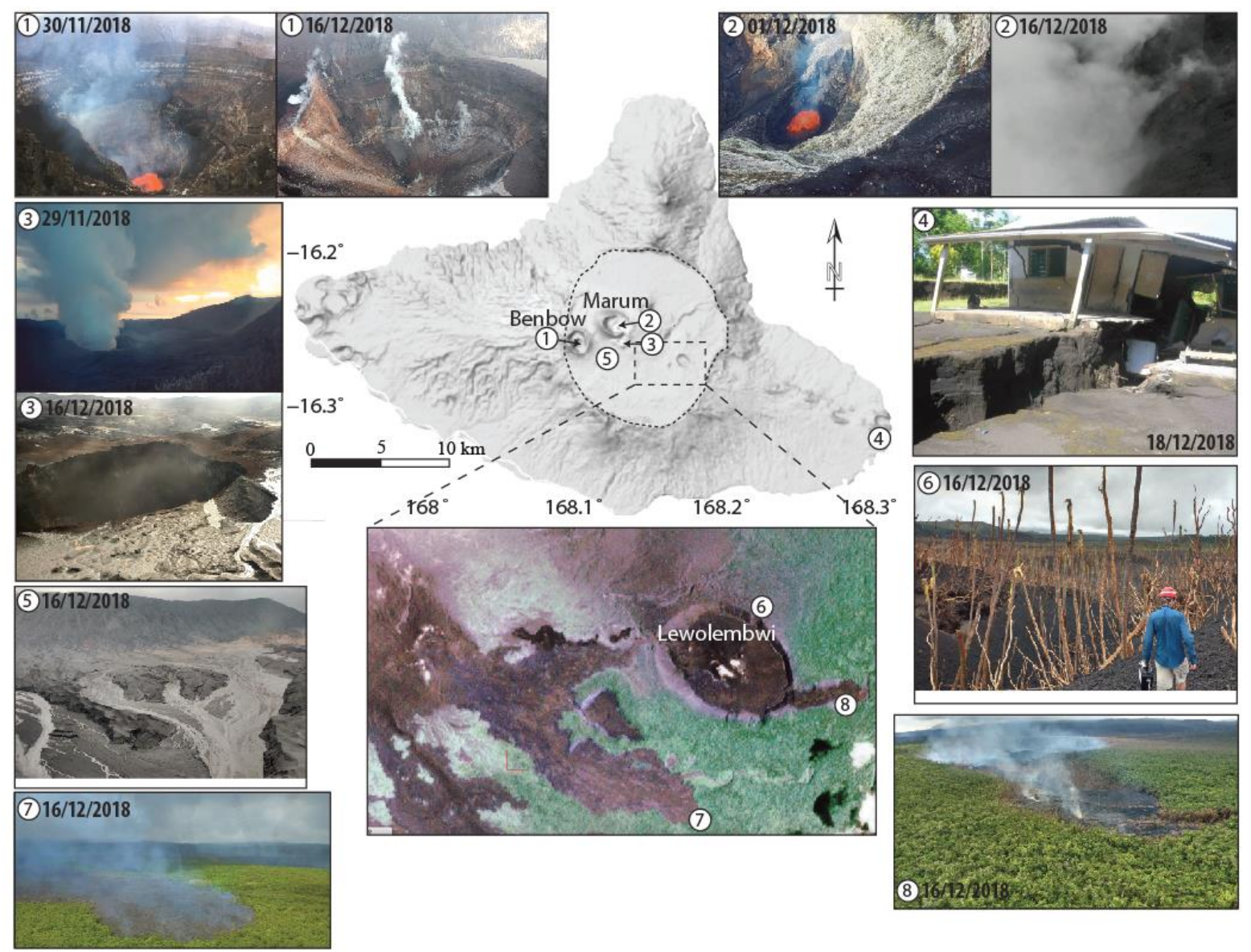

124 Fig. 1 Central panel: shaded hillside view of Ambrym Island (source CNES/Airbus), dotted 125 contour outlines the $\sim 12 \mathrm{~km}$ diameter caldera. Lower panel: True-colour Planet image taken 126 on 31-02-2019 showing the extent of lava flow and scoria deposits (emplaced on 14-16 127 December 2018). Numbers on the central and lower panels show the location of the 128 photographs with corresponding numbers. Panel 1 shows one of two lava lakes at Benbow crater before and after/during the eruption. Panel 2 shows one of three lava lakes at Marum crater before and after/during the eruption. Crater walls around all five original lava lakes partially collapsed, one lava lake was replaced by a water lake by December 16. Panel 3 shows the Maben Mbwelesu or Niri Taten vent before and after/during the eruption. Panel 4 shows the surface deformation and resulting fracturing affecting the coastal village of Pamal, located close to the site of inferred submarine eruption starting on 17December. Panel 5, view of Marum with lahar coming down the flanks of the edifice from all direction whilst no rainfall had occurred, suggesting that groundwater, expelled due to compaction was generating the mud flows. Panel 6, view from the flank of Lewolembwi crater with palm trees blasted and partially buried by scoria. Panel 7, view of the lava flow with active front marked by burning vegetation. Panel 8, view of the fissure running through the Lewolembwi crater 


\section{METHODOLOGY}

\section{Samples}

143 Tephra samples from the intra-caldera eruption were collected on 16 December 2018, North of 144 the Lewolembwi crater (at $16^{\circ} 16^{\prime} 3.65^{\prime \prime S}$; $168^{\circ} 10^{\prime} 13.61^{\prime \prime E}$, sample name AMB2018_FF_S1 and 145 at $16^{\circ} 15^{\prime} 42.42 " S ; 168^{\circ} 10^{\prime} 17.41 " E$, sample name AMB2018_FF_S2). Tephra from both 146 samples were lapilli-size but sample AMB2018_FF_S2, being located further from the fissure 147 was composed of smaller (typically $<1 \mathrm{~cm}$ diameter) lapilli. An ash sample was collected south 148 of the Marum and Benbow craters (at 16 $16^{\prime} 4.29^{\prime \prime} S ; 168^{\circ} 77^{\prime} 3.24 " E$, sample name 149 AMB2018_FF_S3). Tephra samples from the submarine eruption were collected on 18 150 December 2018 (sample name AMB2018_SUB_S1) and 04 February 2019 (sample name 151 AMB2018_SUB_PAMAL_1) from the beach near the coastal village of Pamal. In both cases 152 the pumices were floating and deposited onshore. The exact timing of the deposition of each wave of scoria is unknown. Both samples consist of lapilli size (typically $<1 \mathrm{~cm}$ diameter),

154 highly vesicular fragments. Details on sample processing are provided in the supplementary.

\section{Analyses of major, trace and volatile elements}

Major element compositions of bulk tephra were analysed on a HORIBA-Jobin-Yvon ULTIMA C ICP-AES at Laboratoire Magmas et Volcans in Clermont-Ferrand using the

159 procedure described in Moussallam et al. (2019). Trace element compositions of melt 160 inclusions and glasses were analysed using a laser ablation system associated with an 161 inductively coupled plasma mass spectrometer of the Laboratoire Magmas et Volcans,

162 Clermont-Ferrand (193 nm Excimer Resonetics M-50E laser with an Agilent 7500 ICP-MS).

163 Volatile $\left(\mathrm{H}_{2} \mathrm{O}, \mathrm{CO}_{2}, \mathrm{Cl}, \mathrm{F}, \mathrm{S}\right)$ content in melt inclusions, embayments, and matrix glasses were 164 determined using a Cameca IMS 1280 ion microprobe at CRPG-CNRS-Nancy. Analytical 165 conditions were similar to other volatile studies (e.g., Hauri et al. 2002; Bouvier et al. 2008; 
166 Shimizu et al. 2009; Rose-Koga et al. 2014, 2020.; Moussallam et al. 2015b, 2019). Details of

167 all three methods are provided in the supplementary.

168

169 Volatile and olivine diffusion modelling

170 Concentration profiles recorded in the embayments were fitted by a diffusion model similar to

171 the one of Ferguson et al. (2016), building on the model presented in Moussallam et al. (2019).

172 Chemical gradients (Fe-Mg, $\mathrm{Mn}$ and $\mathrm{Ca}$ ) in olivine crystals were modelled in one dimension

173 using the DIPRA software (Girona and Costa 2013). Details of both methods are provided in

174 the supplementary.

175

176 Assessment of post-entrapment crystallisation.

177 The amount of post-entrapment crystallisation (PEC) for olivine-hosted inclusions was

178 estimated using the Petrolog3 software (Danyushevsky and Plechov 2011). Calculations were

179 performed using the olivine-melt model of Danyushevsky, (2001), the density model of Lange

180 and Carmichael, (1990), the model for melt oxidation of Kress and Carmichael, (1988) and the

181 model of Toplis, (2005) for the compositional dependence of the olivine-liquid Fe-Mg

182 exchange coefficient (Kd). Calculations were performed assuming a system buffered at the

183 nickel nickel-oxide (NNO) equilibrium. Note that calculations in Petrolog3 are performed

184 under anhydrous conditions at $1 \mathrm{~atm}$. As the inclusions showed no sign of iron loss (Fig. 3D),

185 measured FeOt concentration were taken as final concentration. The resulting PEC estimates

186 range from -10 to $5 \%$ with an average of $-3 \%$ and standard deviation of $\pm 3 \%$. Performing the

187 same calculations at the quartz-fayalite-magnetite (QFM) buffer yield similar results with a

188 range from -11 to $3 \%$, an average of $-4 \%$ and standard deviation of $\pm 3 \%$. Given that most

$189(77 \%)$ olivine-hosted inclusions are modelled to have undergone no or negative amounts of

190 PEC we consider that is can safely be assumed that most inclusion have retained their 
entrapment composition and not been affected by any significant amounts of PEC. In addition,

192

193

194

195

\section{RESULTS}

197

198

199

200

201

202

203

204

205

206

207

213 Olivine phenocrysts show a bimodal distribution (Fig. 3A; Table S2; S3 and S4), with a main 214 population around $\mathrm{Fo}_{74}$ in equilibrium with the mafic magma (Fe/Mg olivine $\mathrm{Kd}$ of $0.30 \pm$ 215 0.04), and a second population around $\mathrm{Fo}_{66}$ in equilibrium with the silicic magma (Fe/Mg 
216 olivine $\mathrm{Kd}$ of $0.30 \pm 0.04$ ). Most low $\mathrm{Mg \#}$ and high $\mathrm{Mg \#}$ olivines (37 / 45) are usually

217 homogeneous. However, when included in the mafic magma, low-Mg\# olivines show rounded

218 shapes indicative of dissolution (Fig. 2E), and a small rim with a higher Mg\# (four crystals,

219 hereafter called type 1 reverse zoning). Another four olivine crystals (two from each

220 population) show a more pronounced, large scale reverse zoning (type 2 reverse zoning, see

221 timescales section below). Olivine phenocrysts also often contain glassy melt inclusions that

222 preserve the composition of their parent magma (Fig. 2G). A few high-Mg\# olivine crystals

223 contain large numbers of inclusions and embayments (Fig. 2H), a texture possibly acquired

224 through initial skeletal growth or as a result of dissolution. Clinopyroxene crystals mostly

225 belong to the glomerocrysts originating from the silicic magma and have an average $\mathrm{Mg \#}$ of

22672 (Fig. 3B). Some of those clinopyroxene crystals show evidence of multiple growth stages,

227 dissolution, and oscillatory zoning (Fig. 2F), indicating a protracted history for the cooling and

228 crystallization of the silicic magma. Composition of plagioclase phenocrysts vary from $\mathrm{An}_{85}$ to

$229 \mathrm{An}_{48}$.

230 

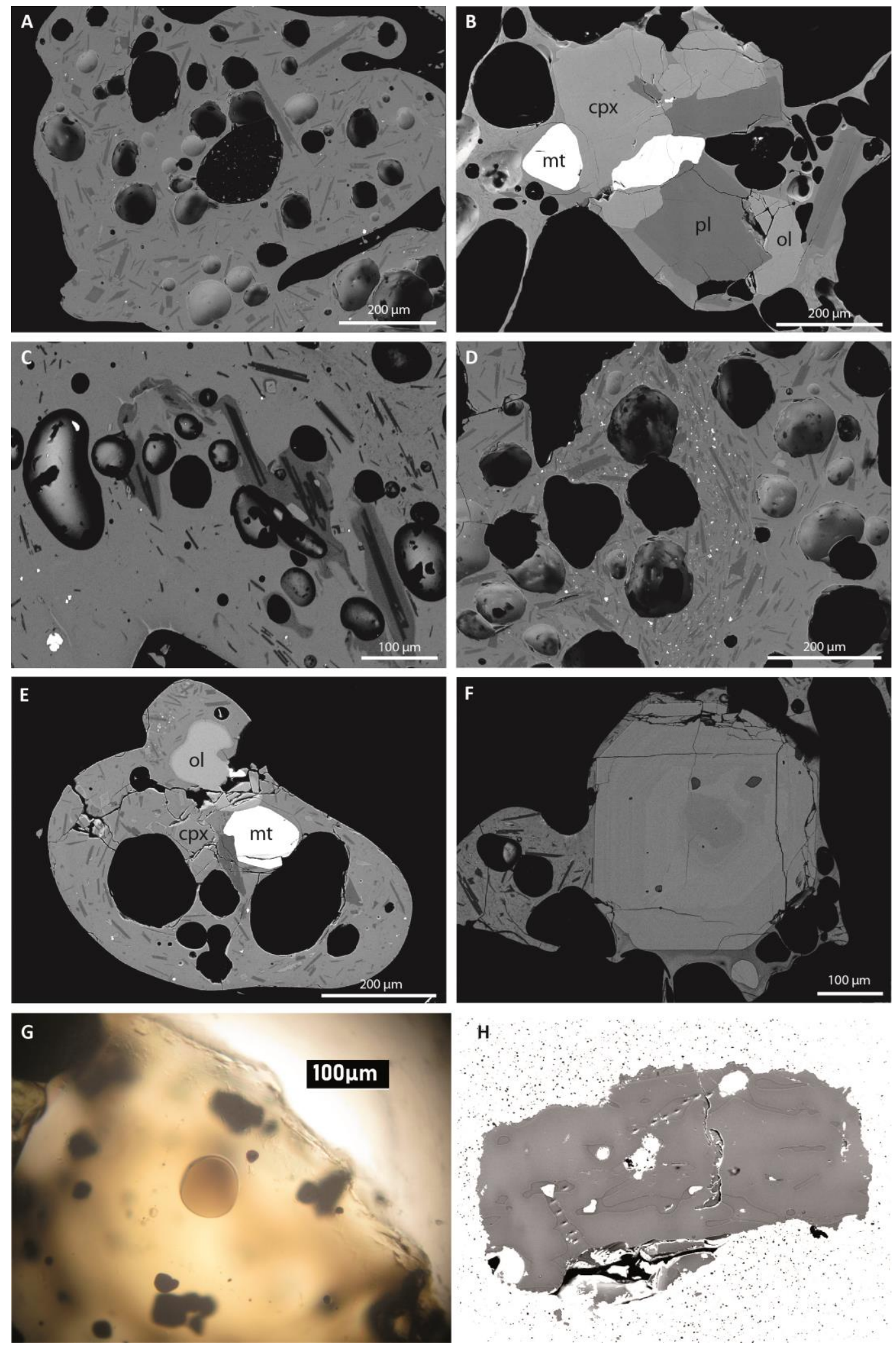

Fig. 2 A-F. BSE microphotographs of typical textures for subaerial and submarine eruptive products: A. Typical texture of the dominant, crystal-poor mafic magma, with microlites of plagioclase and minor olivine, clinopyroxene and magnetite. B. Plagioclase-clinopyroxeneolivine-magnetite glomerocryst surrounded by a small layer of microlite-free silicic melt (darker grey) within a more microlite-rich mafic melt. $\boldsymbol{C}$. Mingling between a crystal-poor mafic melt (lighter grey, dominant) and a silicic melt (darker grey with darker plagioclase 
microlites, less abundant). The upper right side of the picture shows a mafic melt with higher crystallinity. D. Mingling between a crystal-poor and a crystal-rich mafic melts. Both melts contain the same microlite assemblage of plagioclase, olivine, clinopyroxene and magnetite, with less magnetite in the crystal-poor melt. $\boldsymbol{E}$. Another glomerocryst from the silicic melt, now partially dissolved in the mafic melt, with a thin magnesian overgrowth rim around the olivine crystal. $\boldsymbol{F}$. Clinopyroxene megacryst, surrounded by a small amount of silicic glass (dark grey, bottom of picture), in turn surrounded by mafic, microlite-rich glass (left). Evidence of multiple growth stages, dissolution, and oscillatory zoning indicates a protracted history for the silicic magma. Dark glassy melt inclusions in the megacryst core have a trachydacitic composition. G. Transmitted light optical microphotograph of an olivine crystal with a glassy melt inclusion. $\boldsymbol{H}$. BSE microphotograph of an olivine crystal with numerous glassy melt inclusions and embayments (black spots are from SIMS analyses)

\section{Major elements}

The major element composition of melt inclusions, embayments and matrix glasses is given in Tables S1 and reported in Fig. 3 together with bulk rock, matrix glass and melt inclusion analyses from the literature. The composition of melt inclusions and matrix glasses from the 2018 Ambrym eruption is bimodal with modes centred around $\sim 53$ and $\sim 60$ wt. $\% \mathrm{SiO}_{2}$ and compositions ranging from 50 to $63 \mathrm{wt} . \% \mathrm{SiO}_{2}$. Melt inclusions from both the intra-caldera and submarine eruptions capture the full range of compositions. Matrix glasses from the onset of submarine eruption however (sample collected on 18 December 2018, labelled initial phase on subsequent figures) shows very restricted basaltic trachy-andesite composition with no trachy-andesite to trachy-dacite component as opposed to matrix glasses from subsequent submarine eruptive activity (sample collected on 04 February 2019) which show both components and very limited intermediate compositions (i.e. limited chemical mixing). Most pyroxene-hosted melt inclusions (yet not all) are of the more evolved composition while olivine-hosted melt inclusions are of both components with very limited intermediate compositions. This is in agreement with the presence of two populations of olivine phenocrysts and only one population of clinopyroxene phenocrysts (Fig. 3 A, B). Bulk compositions of the intra-caldera and submarine eruptions are both basaltic trachy-andesite. Melt inclusions have

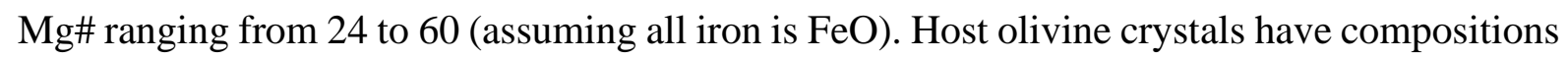


269 ranging from $\mathrm{Fo}_{65}$ to $\mathrm{Fo}_{76}$ with no systematic difference between melt inclusions and olivine

270 from intra-caldera and submarine eruptions. The range of observed composition from the 2018

271 eruption is covered by bulk rock analyses of older deposits. Evolved compositions are rare at

272 Ambrym, the one reported here are similar to the high-potassium (HK) andesite to dacite series

273 described by Picard et al. (1994) previously found only around the Lewolembwi crater. The

274 more primitive compositions reported here on the other hand are typical of the recent historic

275 trachy-basaltic to basaltic trachy-andesite activity, very close in composition to that reported

276 for bulk, matrix glass and melt inclusions in recent deposits of lava expelled from Marum and

277 Benbow craters (Firth et al. 2016; Allard et al. 2016a; Sheehan and Barclay 2016) (Fig. 3). The

278 observed range in melt inclusion compositions can be mostly explained in term of mixing

279 between two end members, a more trachy-basaltic (at $\sim 51 \mathrm{wt} . \% \mathrm{SiO}_{2}$ ) and a more trachy-dacitic

280 (at $\sim 63 \mathrm{wt} . \% \mathrm{SiO}_{2}$ ) component (estimated end member compositions given in Table S1). 

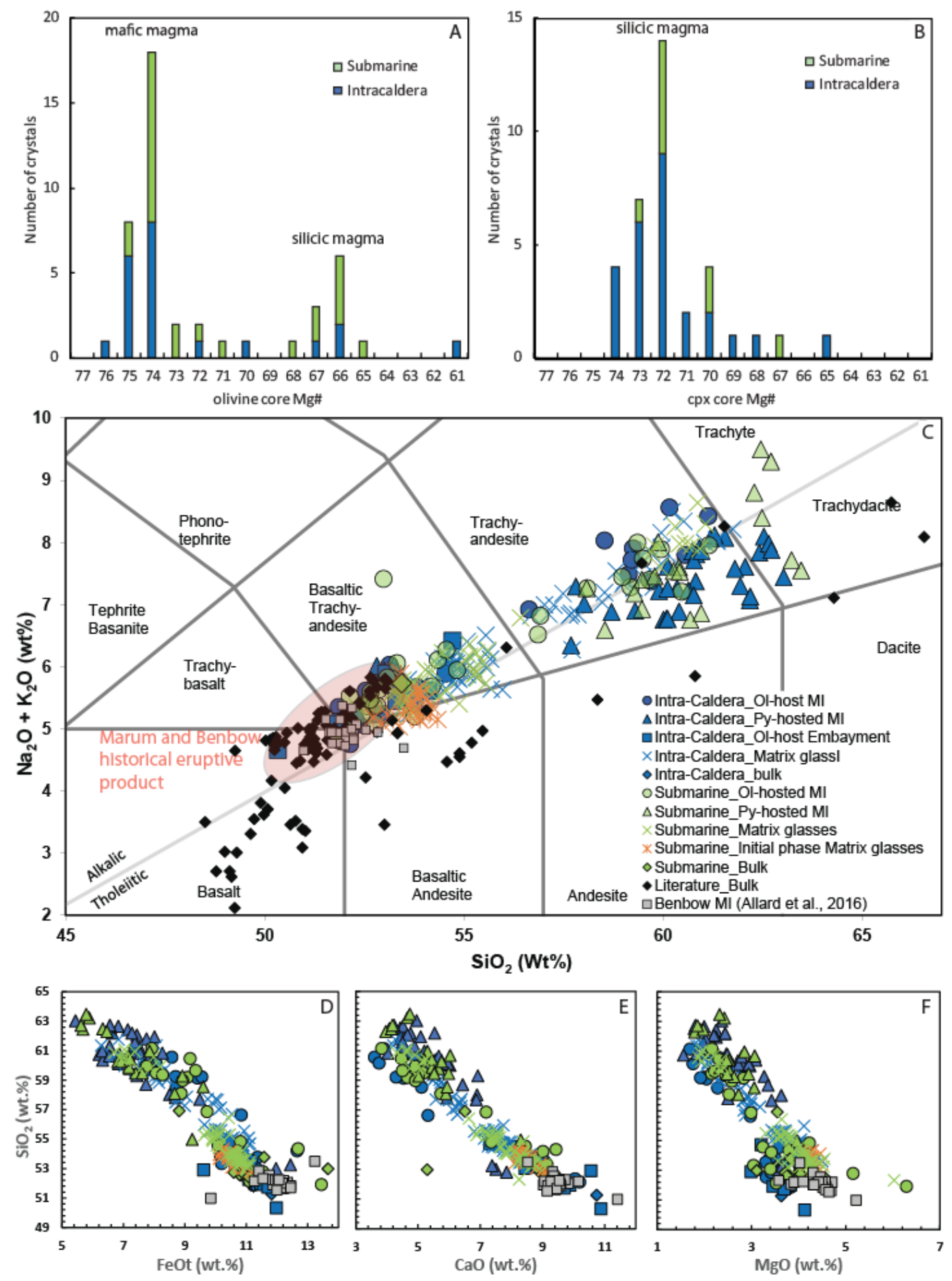

283 Fig. 3 A. Frequency diagram of the Mg\# of olivine cores from the intra-caldera and submarine eruptions. B. Frequency diagram of the Mg\# of pyroxene cores from the intra-caldera and submarine eruptions. $\boldsymbol{C}$. Total alkalis vs silica. Melt inclusions, matrix glasses, and bulk rock compositions (all normalized to $100 \%$ on a volatile-free basis) for the 2018 intra-caldera (blue symbols) and submarine (green and orange symbols) eruptions. Bulk rock literature data are from locations covering the entire island (Gorton 1977; Picard et al. 1994; Firth et al. 2016; Allard et al. 2016a; Sheehan and Barclay 2016). Faded pink ellipse shows the typical composition of bulk lava, matrix glasses and melt inclusions from 1913 to 2014 eruptive products from Marum and Benbow craters (Firth et al. 2016; Allard et al. 2016a; Sheehan and Barclay 2016). D, E and F. $\mathrm{SiO}_{2}$ vs $\mathrm{FeO}_{\text {tot }}, \mathrm{CaO}$ and $\mathrm{MgO}$ diagrams 


\section{Trace elements}

295 Trace and rare earth elements concentrations in melt inclusions and matrix glasses are reported 296 in Table S5 and show no systematic differences between the intra caldera and submarine 297 eruptions albeit limited data. Highly incompatible elements define positive linear correlation 298 offset from the origin (Fig. 4A-C) suggesting mixing between two components or evolution 299 through partial melting (fractional crystallization is expected to result in linear correlation 300 passing through the origin, e.g., Schiano et al. 2010). Plots of incompatible trace element ratios 301 versus abundance (Fig. 4D and E) show a positive correlation also consistent with either mixing 302 or partial melting (as fractional crystallization would result in no variations of the ratio with 303 concentration, e.g., Schiano et al. 2010).
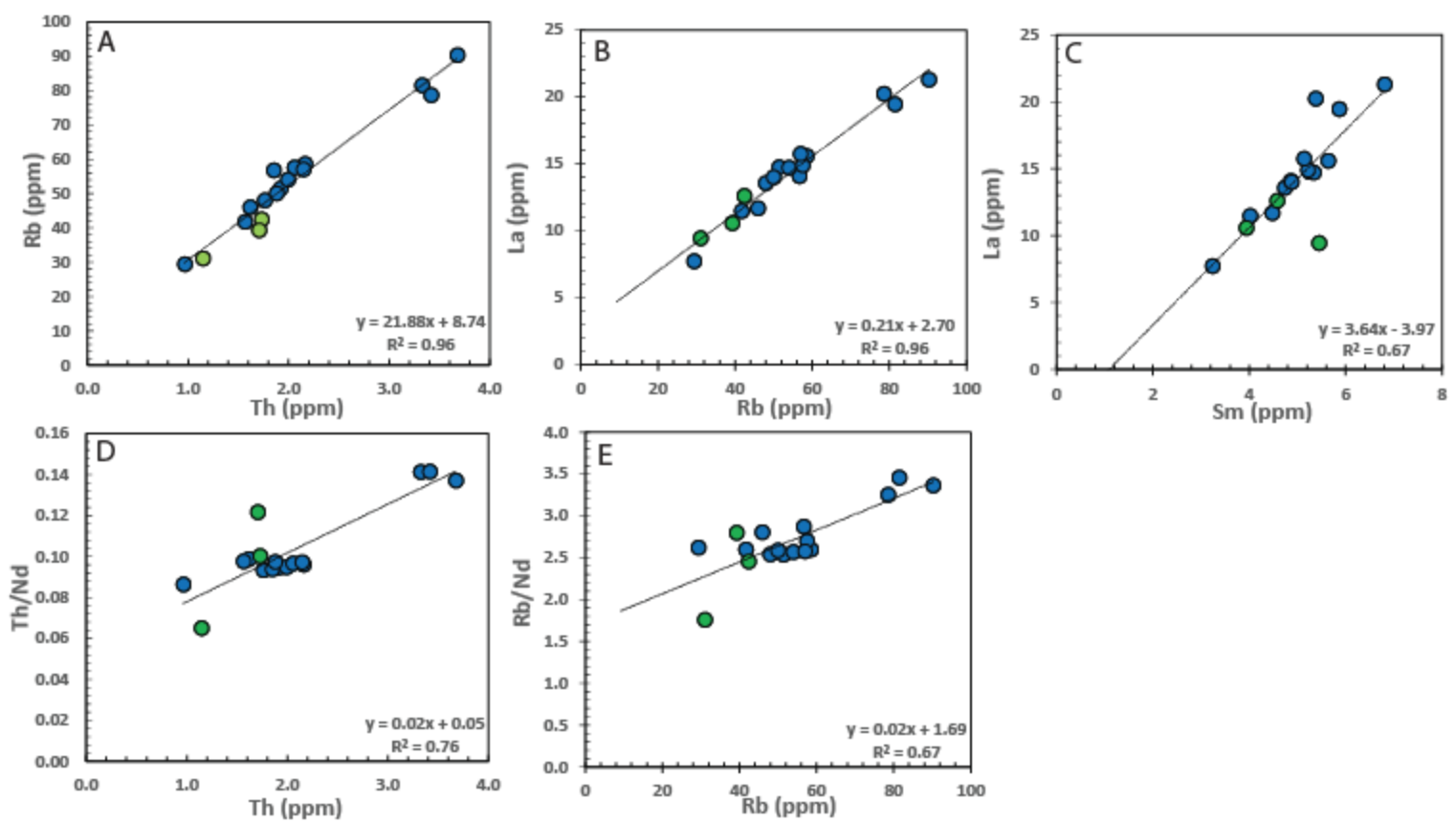

Fig. 4 Trace-element variation diagrams from melt inclusions and matrix glasses from the intra-caldera (blue) and submarine (green) eruption. A. Plot of Rbvs Th. B. Plot of Lavs Rb. C. Plot of La vs Sm. D. Plot of Th/Nd vs Th. C. Plot of Rb/Nd vs Rb. Linear regression lines through all data are presented on each plot 


\section{Volatiles}

311 Volatile contents from melt inclusions, embayments and matrix glasses from both the intra-

312 caldera and submarine eruptions are given in Table S6. In melt inclusions and matrix glasses,

313 chlorine ranges from below detection to $1200 \mathrm{ppm}$, fluorine from 200 to $1000 \mathrm{ppm}$, water from

314 below detection to $2.1 \mathrm{wt} \%, \mathrm{CO}_{2}$ from below detection to $1800 \mathrm{ppm}$ and sulfur from below

315 detection to $1700 \mathrm{ppm} . \mathrm{H}_{2} \mathrm{O}$ and $\mathrm{CO}_{2}$ values in melt inclusions are regarded as minimum values

316 from the time of entrapment given that $\mathrm{H}^{+}$diffusion out of the melt inclusion (e.g., Chen et al.

317 2011) and $\mathrm{CO}_{2}$ diffusion in shrinkage bubbles (e.g., Anderson and Brown 1993) cannot be

318 discarded.

$320 \mathrm{CO}_{2}$ vs $\mathrm{H}_{2} \mathrm{O}$ abundance in melt inclusion does not follow a single degassing trend but might instead reflect the combination of several distinct degassing paths. Sulfur abundance is partly controlled by degassing as evidenced by the systematic difference between melt inclusions and matrix glasses. The presence of sulfides in some melt inclusions (Fig. 5) indicates that the melt must have been at saturation with a liquid sulfide phase prior to ascent and degassing. The large size of the sulfides ( $20 \mu \mathrm{m}$, Fig. 5 and MI photographs in appendix) precludes their formation from secondary processes. This is further indicated by the observed negative correlation between the maximum sulfur content of melt inclusions and their $\mathrm{FeO}$ content following the expected trend of sulfur content at sulfide saturation (Fig. 5). Both chlorine and fluorine contents are correlated with melt composition, the basaltic melts end member having around $450 \mathrm{ppm} \mathrm{Cl}$ and $550 \mathrm{ppm} \mathrm{F}$ and the dacitic melt end member having around $1100 \mathrm{ppm} \mathrm{Cl}$ and $800 \mathrm{ppm}$ F. The original water content of the more mafic and more silicic melts mostly overlaps, although the mafic component has melt inclusions with low $(<0.75$ wt.\%) water content that are largely absent from the more silicic component indicating more extensive

334 shallow crystallisation. Mafic melt inclusions from the submarine eruption tend to record 
335 higher water and $\mathrm{CO}_{2}$ content than mafic melt inclusions from the intra-caldera eruption. There 336 are no correlations between the melt inclusion $\mathrm{CO}_{2}$ content and their major element 337 composition.

338
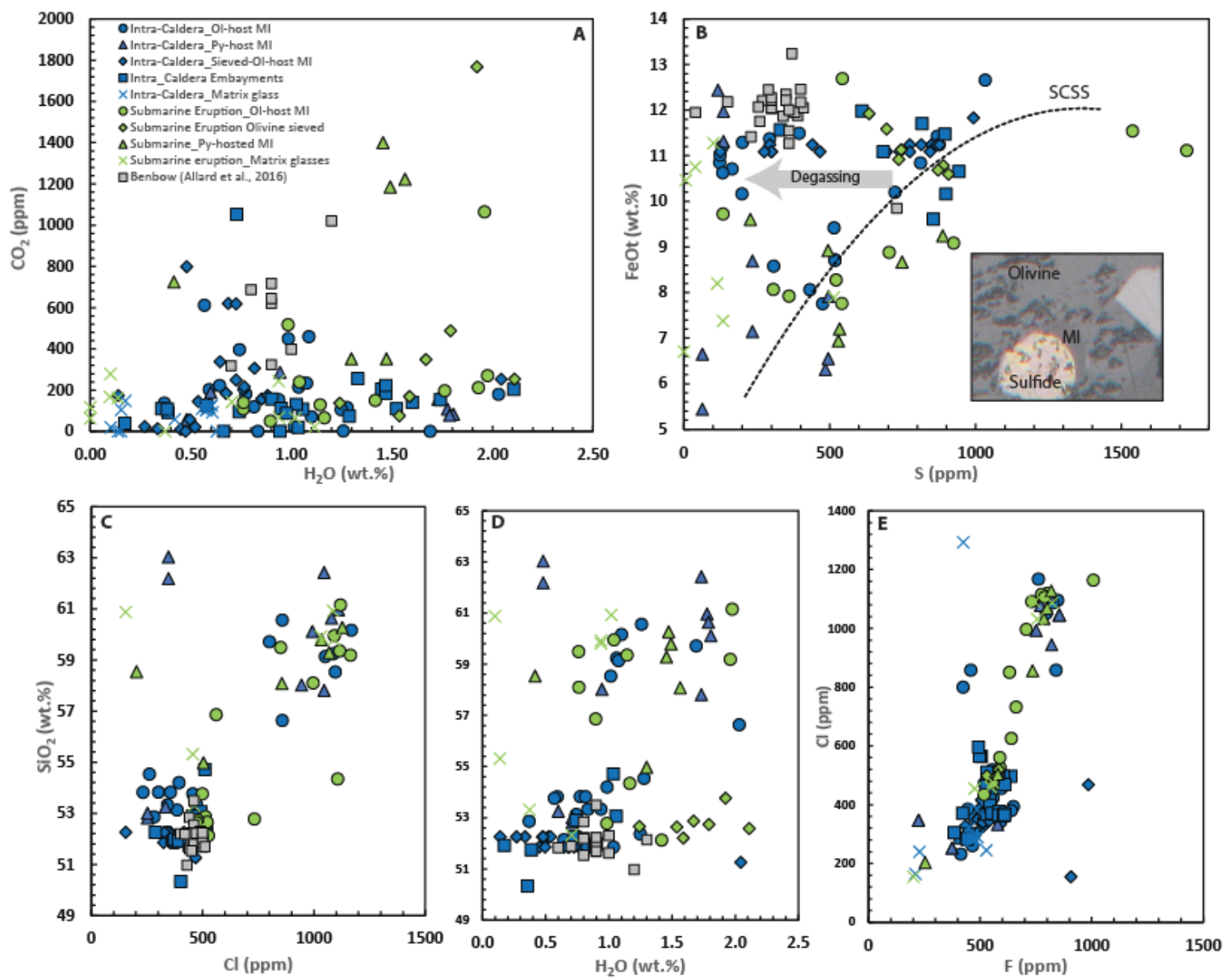

Fig. 5 Volatile elements abundance in melt inclusions, embayments and matrix glasses from

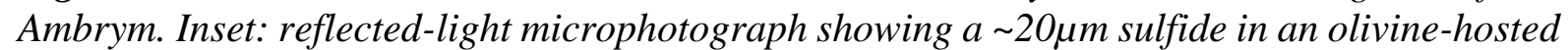
melt inclusion (olivine AMB A12). Dotted curve on panel B show calculations of the sulfur content at sulfide saturation (SCSS) calculated at $1200^{\circ} \mathrm{C}, 100 \mathrm{MPa}$ using the model of Smythe et al. (2017)

\section{Geothermobarometry and volatile saturation pressure}

348 Melt inclusions entrapment pressures were calculated using the model of Iacono-Marziano et al., (2012) for $\mathrm{H}_{2} \mathrm{O}-\mathrm{CO}_{2}$ saturation pressure. They yield entrapment pressures between 5 and $280 \mathrm{MPa}$ (Fig. 6). Given the above-reported error on the volatile content determination and the error on the model, the results can conservatively be taken to be precise at $\pm 20 \%$. Yet, as 
352 discussed previously, $\mathrm{H}_{2} \mathrm{O}$ and $\mathrm{CO}_{2}$ values are to be considered as minimum values due to

353 possible diffusion of both species. The entrapment pressures are therefore also to be taken as

354 minimum pressure estimates. Another reason to assume these pressure estimates are minimum

355 is that the model of Iacono-Marziano et al., (2012) that we use here has been shown, at least

356 for alkali basalt compositions to overestimate the amount of water that can be in dissolved in

357 the melt (see Fig. 13 in Shishkina et al. 2014).

358

359 Shown in Fig.6 is the absence of systematic difference between the entrapment pressures of

360 the more basaltic and the more dacitic melt inclusions. Both magmas appear to have

361 crystallized over similar pressure ranges. Similarly, we see no strong systematic differences

362 between the entrapment pressure of melt inclusions from crystals erupted during the intra-

363 caldera and those erupted during the submarine eruption, although we note that the five most

364 deeply entrapped (180 to $280 \mathrm{MPa}$ ) inclusions are all from crystals erupted in the submarine

365 eruption suggesting contribution from a deeper magma that was not present in the intra-caldera

366 eruption. Similarly, all the most shallowly entrapped (<24 MPa) melt inclusions are from

367 crystals erupted during the intra-caldera eruption suggesting that the shallowest (top $750 \mathrm{~m}$ )

368 portion of the magmatic system contributed only to the intra-caldera eruption and might have

369 been emptied prior to the submarine eruption.

370 The volatile content of matrix glasses erupted during the submarine eruption should

371 theoretically reflect the hydrostatic pressure under which they were erupted. Volatile contents

372 indicate pressures of last equilibration in the range of 2.5 to $50 \mathrm{MPa}$. We attribute this large

373 range to the rapid ascent (see ascent rates section) that would have impeded equilibrium

374 degassing (Pichavant et al. 2013) and to the potentially explosive nature of the submarine

375 eruption preventing re-equilibration at extrusion pressure. Taking the lowest recorded 
376

377

378

equilibrium pressure as the maximum emplacement depth suggests that the submarine eruption took place less than $250 \mathrm{~m}$ underwater.

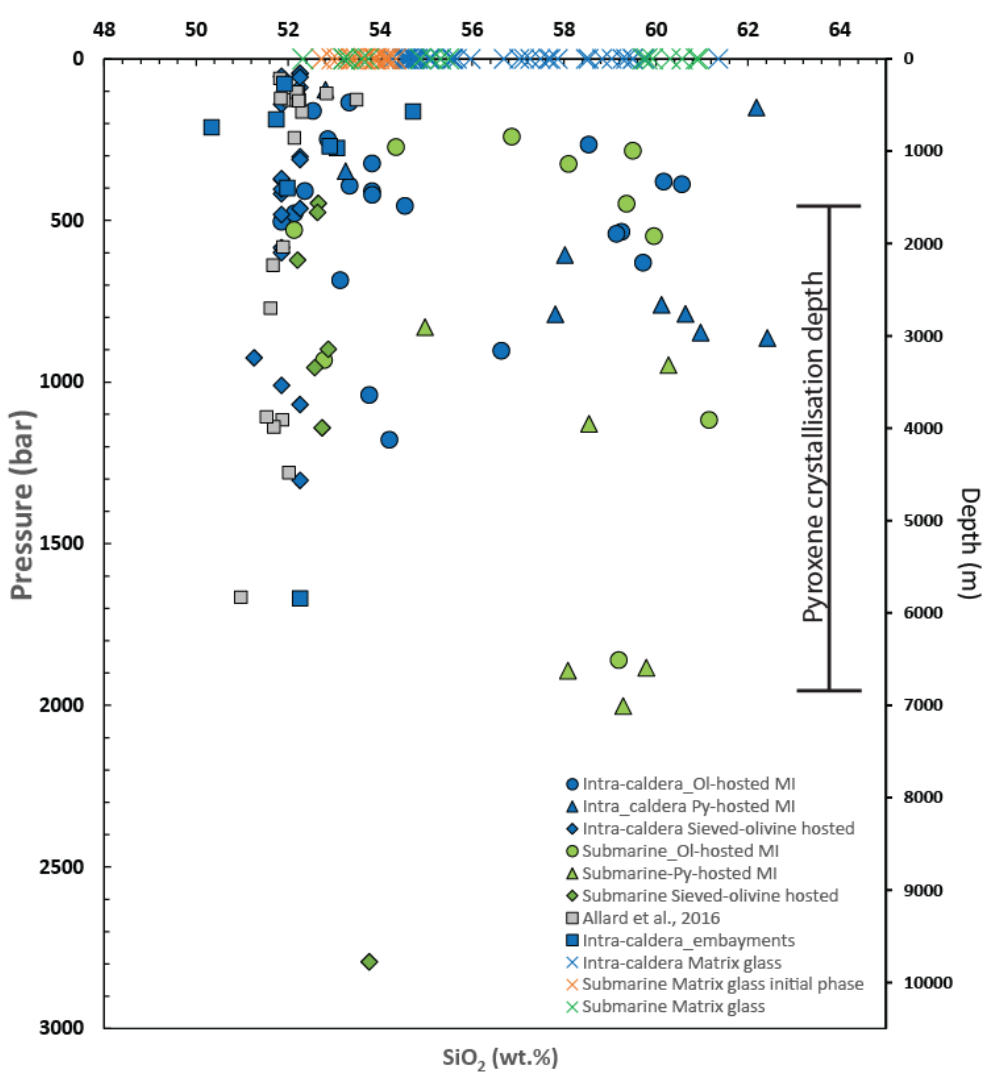

380 Fig. 6 Melt inclusions entrapment pressure calculated from $\mathrm{H}_{2} \mathrm{O}-\mathrm{CO}_{2}$ saturation pressure 381 using the model of Iacono-Marziano et al., (2012) for all data shown including the data from Allard et al., 2016, compared to melt $\mathrm{SiO}_{2}$ content. Note that all matrix glasses are arbitrarily plotted at 1 bar

384

385 Since all glasses are saturated with olivine, pre-eruptive temperatures were calculated using the

386 olivine-melt thermometers of Ford et al. (1983) and Beattie et al. (1993). Both thermometers

387 give near-identical results for the mafic glasses (Ford: $1125{ }^{\circ} \mathrm{C}$; Beattie: $1112{ }^{\circ} \mathrm{C}$; average of

$\left.3881120^{\circ} \mathrm{C}\right)$. The silicic melt was slightly colder, with estimated temperatures between 1074

389 (Beattie) and $1112{ }^{\circ} \mathrm{C}$ (Ford), for an average temperature of $1100{ }^{\circ} \mathrm{C}$. Taking into account a 
391 estimated pre-eruptive temperatures of $1078{ }^{\circ} \mathrm{C}$ for the mafic magma and $1054{ }^{\circ} \mathrm{C}$ for the silicic magma, using the model of Médard and Grove (2008).

393 Previous work on clinopyroxene-based thermobarometry for the 2005-2007 eruptive products 394 of the then-active lava lakes were published by Sheehan and Barclay (2016). Using three 395 different thermometer/barometer combinations (Putirka et al. 2003; eq. (32a) and (32d) of 396 Putirka et al. 2008; eq. (30) and (33) of Putirka et al. 2008), they report a tight range of average storage pressures for Mg\#74-76 clinopyroxenes between 390 and $485 \mathrm{MPa}$. Work on a larger range of eruptive products (from 1913 to 2014, clinopyroxenes Mg\#61-74) by Firth et al. (2016) using eq. (30) and (33) of Putirka produces a similar pressure range of $433 \pm 86 \mathrm{MPa}$ (excluding one of their datapoint at $1000 \mathrm{MPa}$ ). Using the same eq. (30) and (33) of Putirka et

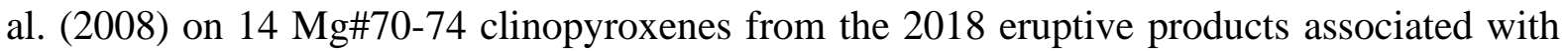
melt inclusions returns average crystallisation pressures of $145 \pm 59 \mathrm{MPa}$ at temperatures of $1042 \pm 25^{\circ} \mathrm{C}$, in excellent agreement with the pre-eruptive temperature for the silicic magma estimated from olivine-melt thermometry. There is no overlap between our dataset and previous datasets (Sheehan and Barclay 2016; Firth et al. 2016), suggesting that two different storage levels were sampled by the 2018 eruption and previous eruptions. Since most clinopyroxene crystals (if not all) come from the silicic magma, we use an average melt composition of the silicic melt inclusions, and average water content of $1.2 \mathrm{wt} \%$ to apply the same combination of thermometer and barometer to a larger dataset of 81 clinopyroxene 410 phenocryst analyses. The resulting pre-eruptive pressure is $121 \pm 75 \mathrm{MPa}$ at a temperature of $4111034 \pm 8{ }^{\circ} \mathrm{C}$, identical to the values obtained with the more restricted dataset. Although using 412 the same barometer, no value came within error of the pressures determined by Firth et al. 413 (2016) and Sheehan and Barclay (2016), confirming that the 2018 eruption sampled a shallower 414 storage system than previous eruptions. Assuming a crustal density of $2900 \mathrm{~kg} \cdot \mathrm{m}^{-3}$, those 415 crystallization pressure translates into crystallization depths of $4.3 \pm 2.6 \mathrm{~km}$ (or $5.1 \pm 2.1 \mathrm{~km}$ 
416 for the restricted dataset of inclusion-bearing clinopyroxene phenocrysts), in excellent

417 agreement with the deeper part of the storage system imaged through saturation pressure of melt inclusions (see also Allard et al. 2016a).

419

\section{Residence time}

421 The eight olivine crystals that showed significant (greater than $2 \%$ ) differences in their 422 forsterite content were investigated through detailed (1 to $10 \mu \mathrm{m}$ step) compositional EMP 423 profiles. All 8 crystals record reverse zoning with core compositions around Fo65 to Fo70 and 424 rim compositions around $\mathrm{Fo}_{70}$ to $\mathrm{Fo}_{76}$. These reversely zoned crystals are rare because the more 425 silicic magma is volumetrically much smaller than the primitive one and contains much fewer 426 olivine (Fig. 3). As a result, the vast majority of olivine crystals in the mixed deposit are from the mafic component and are in equilibrium with the carrier melt, which is dominantly of mafic composition, hence showing no significant zoning. The chances of finding olivine crystals from the silicic component that have been in contact with the mafic component and started reequilibrating diffusively are small and only 8 such reversely zoned olivine crystals were found. Two very different diffusion profiles are recorded by these crystals; type 1 profiles ( 4 crystals) show very sharp compositional variations occurring over a narrow 5 to $20 \mu \mathrm{m}$ distance to the crystal edge, while the other 4 (type 2 profiles) show very smooth core to rim compositional variations occurring over distances greater than $60 \mu \mathrm{m}$ from the crystal edge. Diffusion profiles 435 for these 4 crystals could not be modelled accurately as a clear "plateau" in terms of composition was not constrained. Their profiles however are consistent with strict minimum diffusion timescales on the order of years. The four crystals that displayed sharp compositional 438 profiles were modelled using the DIPRA software (Girona and Costa 2013) for diffusion 439 timescale using the variations in $\mathrm{Fe}-\mathrm{Mg}, \mathrm{Mn}, \mathrm{Ni}$ and $\mathrm{Ca}$ content. Results together with the full 440 list of parameters used for the modelling are given in supplementary Table S7. Modelled Fe- 
$441 \mathrm{Mg}, \mathrm{Mn}$ and Ni diffusion profiles match the natural data extremely well and yield similar time

442 estimates (Fig. 7) confirming that these natural profiles are the result of diffusion and not

443 growth processes. Modelled Ca diffusion profiles tend to have much higher discrepancy, carry

444 large uncertainties, and do not always yield diffusion timescales consistent with those obtained

445 from the $\mathrm{Fe}-\mathrm{Mg}, \mathrm{Mn}$ and Ni diffusion profiles. Any modelled diffusion profile yielding $\geq 15 \%$

446 discrepancy with the data was discarded.

447

448 Of the four olivine crystals for which diffusion timescale was investigated, one is from the 449 intra-caldera eruption while the other three are from the submarine eruption. The crystal from 450 the intra-caldera eruption record compositional profiles consistent with a diffusion timescale 451 of less than a day. Olivine crystals from the submarine eruption record compositional profiles 452 consistent with diffusion timescales of about two days indicating that mixing of these olivine 453 crystals (originating from the silicic magma) into the more primitive magma took place one to 454 a few days prior to eruption (Fig. 8).

456 The presence of four olivine phenocrysts with diffusion profiles indicative of long-term 457 diffusion, as well as frequent oscillatory zoning within the clinopyroxene phenocrysts indicate 458 the possibility of periodic interaction between the silicic and mafic magmatic systems, with at 459 least one interaction occurring more than a year prior to the 2018 eruption. 

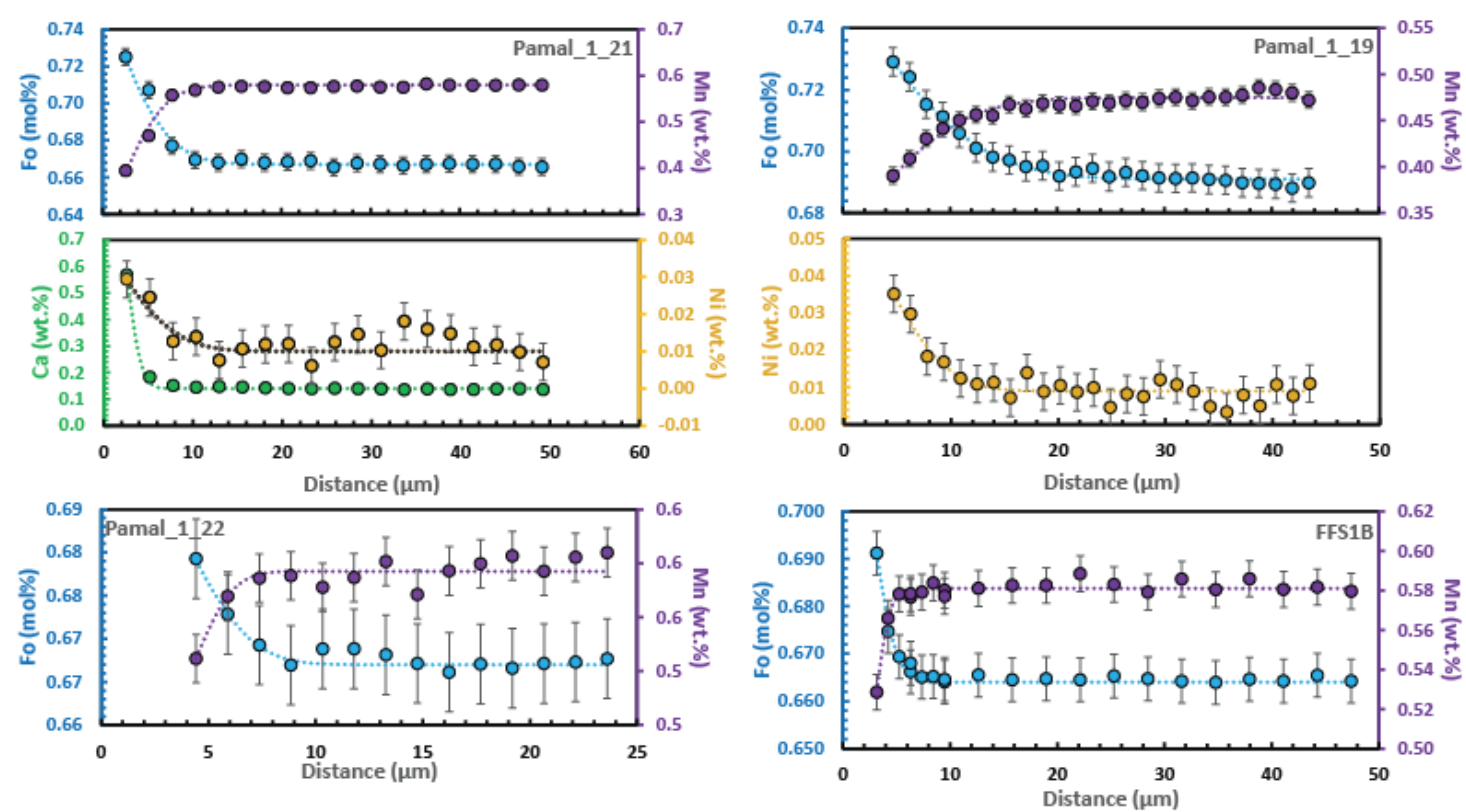

461

462 Fig. 7 Results of diffusion modelling (dotted lines) compared to Fo, Mn, Ni and Ca 463 concentrations profiles (measured by EMPA, error bars are $2 \sigma$ ) in four olivine crystals from 464 the intra-caldera and submarine eruptions. Modelling was performed using the DIPRA 465 software (Girona and Costa 2013) 

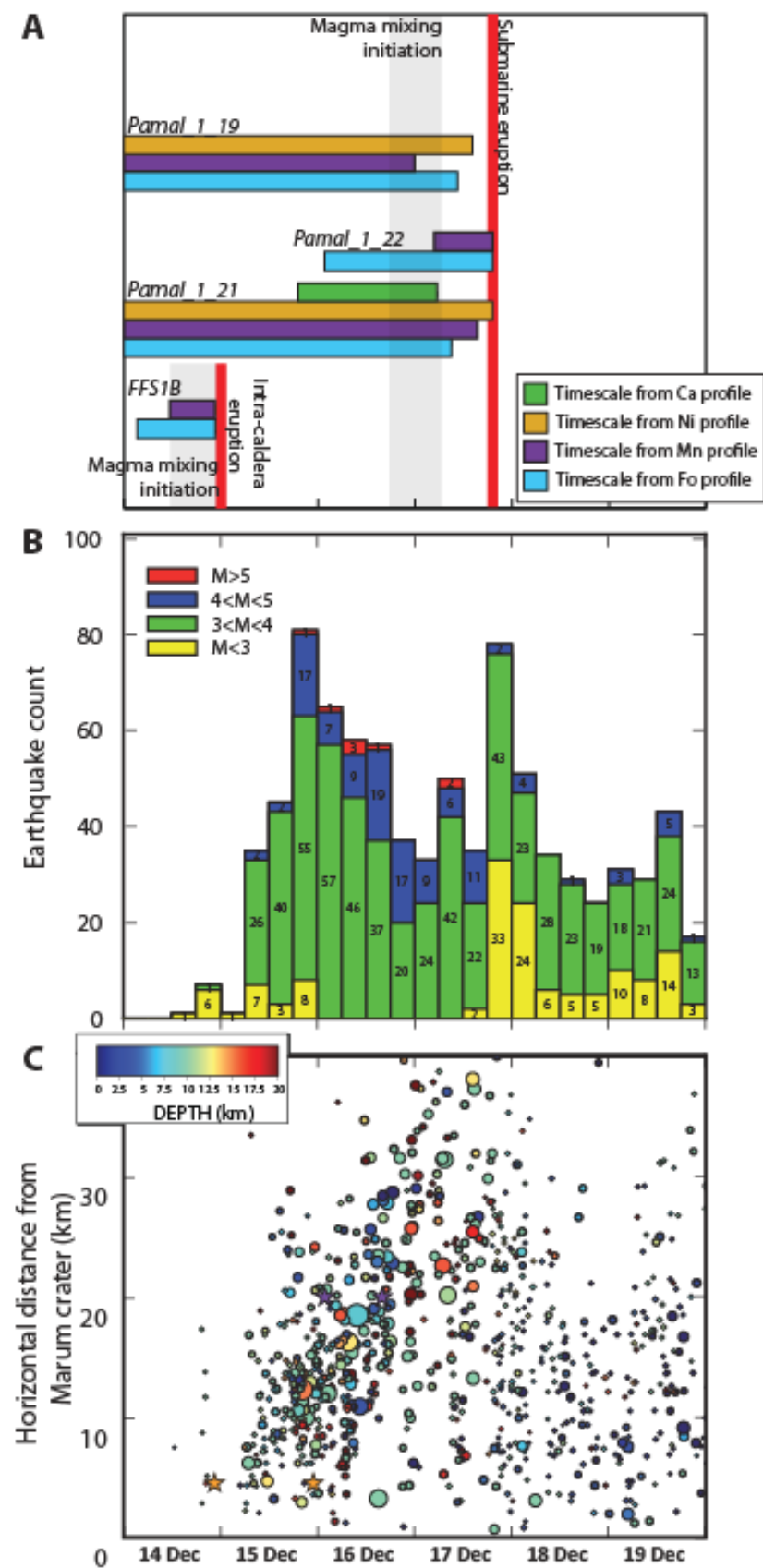

468 Fig. 8 A. Summary of diffusion timescales obtained from modelling $F o$, Mn, Ni and Ca diffusion profile. Each coloured bar shows the range of possible diffusion timescale taking into account unknown crystal orientation (modelling along the a and $c$ axes) and the error on each diffusion model (derived from $2 \sigma$ error on EMPA and a $25^{\circ} \mathrm{C}$ error on the estimated temperature). Note that calculated diffusion timescale, obtained in unit of time, are presented here in term of date assuming that diffusion stopped at the onset of eruption. The time window where all diffusion timescale overlap is taken to represent the time at which diffusion started which we interpret as the initiation of magma mixing (time at which olivine crystals became in contact with a more primitive melt and started developing reverse zoning. B. Evolution of seismicity at Ambrym in the period 14 to 20 of December (activity prior to 14 December is minimal), adapted from Shreve et al., (2019). C. Evolution of seismicity as a function of distance from Marum, with earthquakes coloured by depth, adapted from Shreve et al., (2019) 


\section{Ascent rates}

482 Volatile diffusion modelling was performed to match the measured $\mathrm{H}_{2} \mathrm{O}$ and $\mathrm{S}$ concentration profiles (obtained by SIMS) along three melt embayments from the intra-caldera and one from the submarine eruption. All embayments are from melt compositions close to the basaltic end member (i.e. main Marum and Benbow magma). Best fit solutions of the diffusion models are shown in Fig. 9 with initial conditions, model parameters and results given in Table S8. For each embayment we report the results of two type of models: one considering diffusion of the specie of interest only, the other considering diffusion of both species and minimizing error on the fit for both species simultaneously. In all cases, best fit of S profiles only, always result in lower decompression rate estimates (from 0.01 to $0.6 \mathrm{MPa} / \mathrm{s}$ ) than best fit of $\mathrm{H}_{2} \mathrm{O}$ profiles (from 0.39 to $2.7 \mathrm{MPa} / \mathrm{s})$. Embayment $\mathrm{PG} 11$ and $\mathrm{AF} 2$ show $\mathrm{H}_{2} \mathrm{O}$ and $\mathrm{S}$ profiles that can be fitted well simultaneously (Fig. 9), yielding decompression rates of 2.3 and $2.7 \mathrm{MPa} / \mathrm{s}$ respectively. These two embayments are also the ones recording decompression from highest initial pressure (115 and $68 \mathrm{MPa}$ respectively). Embayments AD5 and AE38 show significant discrepancy between modelled and measured profiles when trying to fit both species simultaneously. These two embayments record decompressions from lower pressures (34 and $37 \mathrm{MPa}$ respectively). A probable explanation is that PG11 and AF2 record direct magma ascent to the surface (from 4 and $\sim 2.5 \mathrm{~km}$ depth respectively) while AD5 and AE38 might have experienced a more complex decompression path, only partially equilibrating at $\sim 1 \mathrm{~km}$ depth prior to ascent or ascending in

500 discrete steps. We consider that our best estimates of magma ascent rates during the intra501 caldera and submarine eruptions are hence given by the simultaneous modelling of $\mathrm{H}_{2} \mathrm{O}$ and $\mathrm{S}$ diffusion profiles in embayments AF2 and PG11 respectively, giving ascent rates of 340 and $290 \mathrm{~km} / \mathrm{h}(95$ and $80 \mathrm{~m} / \mathrm{s})$ respectively. This corresponds to magma travel times of about 30

504 seconds from $\sim 2.5 \mathrm{~km}$ depth to the surface during the intra-caldera eruption and of 1 minute 505 from $\sim 4 \mathrm{~km}$ depth to the surface during the submarine eruption. These ascent rates are 
506 extremely high. They are, by far the fastest estimates based on the volatile diffusion in

507 embayment method to date (see compilation in Moussallam et al. 2019) and are comparable to

508 estimates based on bubble number density for the andesitic 1997 Soufriere Hills eruption (12-

$509260 \mathrm{~m} / \mathrm{s}$; Giachetti et al. 2010) and basaltic-andesite 1986 Izu-Oshima (60-160 m/s; Toramaru

510 2006) eruptions.

511

512 An estimated $13 \times 10^{\wedge} 6 \mathrm{~m}^{3}$ of basaltic magma was degassed during the intra-caldera eruption in

513 about a day (Shreve et al. 2019) making it a magnitude 3.6 eruption with a $\log 10$ mass eruption

514 rate (MER) of 5.6. The amount of material erupted during the submarine eruption is unknown.

515 If we consider the volume of magma in the lateral dike (419 to $532 \times 10^{\wedge} 6 \mathrm{~m}^{3}$, Shreve et al.

516 2019) as representative for an eruption period of two days the submarine eruption would be of

517 magnitude 5.2 with a $\log 10$ MER of 7 (but note that the base assumption here is not verifiable

518 and these values should not be quoted). The point is that decompression rates of 2.7 and 2.3

$519 \mathrm{MPa} / \mathrm{s}$ obtained for the intra-caldera and submarine eruptions respectively are much higher

520 than those obtained for eruptions of comparable magnitude using the same technique (see Fig.

52113 in Moussallam et al. 2019). Whether these fast ascent rates are exceptional for basaltic

522 magmas will only become apparent as more eruptions are studied but to date they are by far

523 the highest.

524

525 From a simple mass conservation argument, the mass eruption rate and ascent velocity can be

526 used to estimate the conduit radius using:

$527 \quad M=\pi r^{2} \rho u$

528 where $M$ is mass eruption rate (in $\mathrm{kg} / \mathrm{s}$ ), $\mathrm{r}$ is the conduit radius (in $\mathrm{m}$ ), $\rho$ is the magma density

529 in $\left(\mathrm{kg} \cdot \mathrm{m}^{-3}\right)$ and $u$ is the velocity in $\left(\mathrm{m} \cdot \mathrm{s}^{-1}\right)$. This would yield a conduit radius of about $1 \mathrm{~m}$ for 
530 the intra-caldera and $4 \mathrm{~m}$ for the submarine eruption but we note that such an approach is over-

531 simplistic as the ascent rate is not a constant and should be much higher at the surface than the

532 average value calculated from the embayment technique (which assumes a constant

533 decompression rate) and the eruption (at least the intra-caldera one) occurred along fissures

534 and not a circular vent.

535
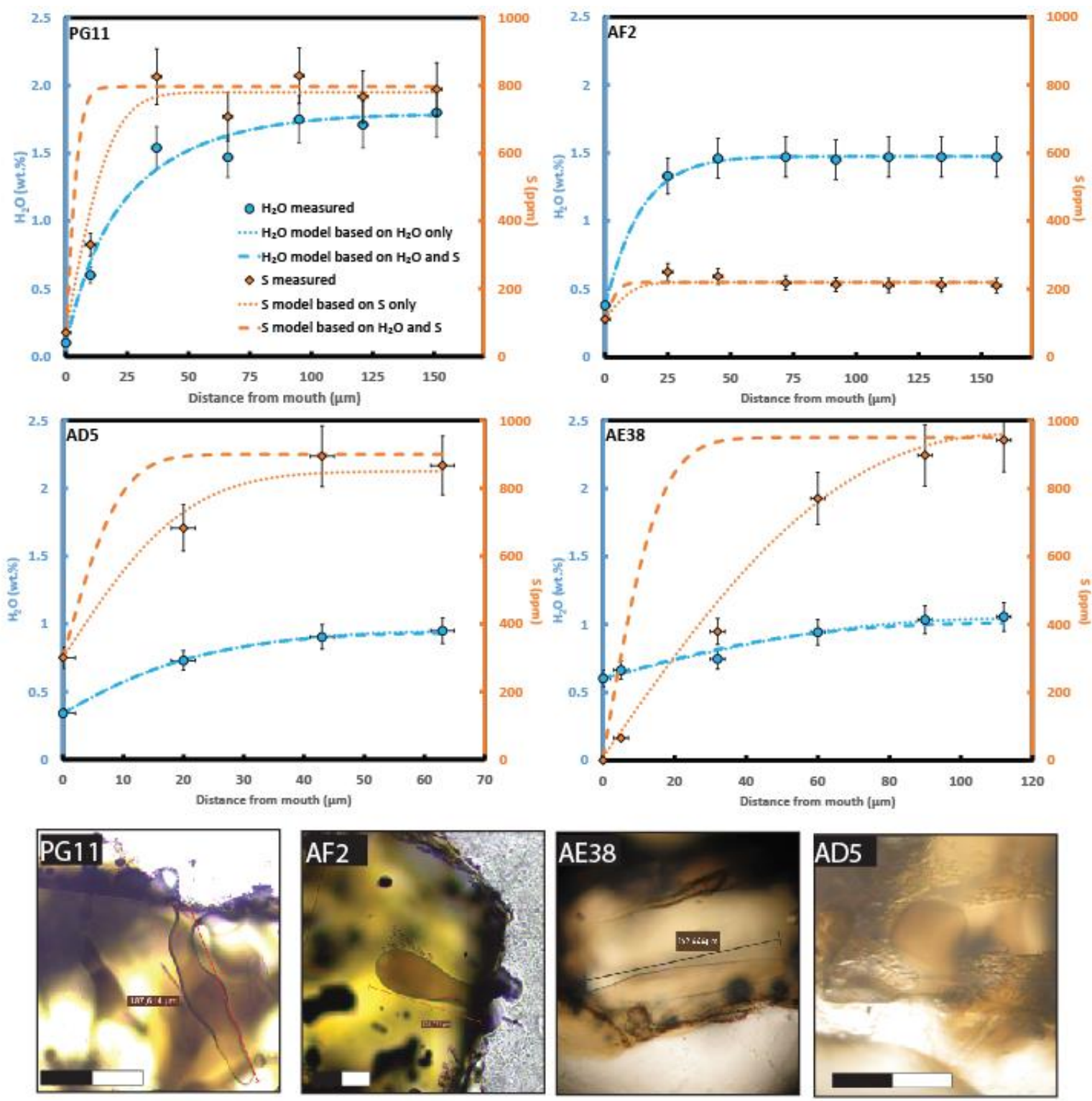

537 Fig. 9 Results of diffusion modelling compared to concentrations (measured by SIMS) for $\mathrm{H}_{2} \mathrm{O}$ 538 and $S$ in three melt embayments from the intra-caldera and one (PG11) from the submarine eruption of Ambrym. Best fit results are shown for two type of models, one (dotted lines) considering diffusion of the specie of interest only, the other (dashed lines) considering 
541 diffusion of both species hence minimizing error on the fit for both species simultaneously.

542 Lower row show microphotograph of each embayment, scale bar represents $100 \mu \mathrm{m}$ length

543

\section{DISCUSSION}

\section{The Ambrym plumbing system}

546 The crystals and melt inclusions erupted during the 2018 eruption paint a new picture of the

547 plumbing system feeding Ambrym volcano. It is clear from this study and previous work on

548 recent deposits (Firth et al. 2016; Allard et al. 2016a; Sheehan and Barclay 2016) that the main

549 magmatic system underneath Marum and Benbow is of basaltic to basaltic-trachy-andesite

550 composition. Our results, together with previous melt inclusion studies (Allard et al. 2016a) all

551 point to this main magmatic system being vertically extensive, with no clear depth horizon of magma repose/accumulation (Fig. 10). Taking into account the clinopyroxene barometry results of Firth et al. (2016) and Sheehan and Barclay (2016), this vertical magma system might extend to at least $14 \mathrm{~km}$ depth, although only the shallowest part of this system was involved in the 2018 eruption. Evidence for this shallow plumbing system reaching up to the surface is provided by the very shallow entrapment pressures of a significant number of melt inclusions, as well as the presence of degassed magma batches, present as a microlite-rich mingled component in the scoriae. The presence of degassed magma is typical of open conduit magmatic systems (e.g., Lautze and Houghton 2005; Gurioli et al. 2014), and evidence of magma convection in the conduits below lava lakes (e.g., Kazahaya et al. 1994; Moussallam et al. 2015b), as was probably the case prior to the 2018 eruption.

The additional information carried in the 2018 eruption deposits is the clear identification of a

564 second magmatic branch, of trachy-andesitic to trachy-dacitic composition. This branch also appears vertically extensive (Fig. 10). We hypothesise that it must be located underneath the 
crater and a lava flow directly north of it that was emplaced in 1986 (Robin et al. 1991; Picard et al. 1994), as already proposed by Picard et al. (1994). This magmatic batch possibly extends down to $7 \mathrm{~km}$, but not as deep as the main mafic magmatic branch.

570

571 The primitive and evolved magmatic branches are clearly chemically related (Fig.3 and Fig.4).

572 We hypothesise that the evolved, trachy-andesitic to trachy-dacitic magma was previously 573 linked at depth to the same parental source as the more primitive trachy-basaltic magma but that this eastern branch was cut-out from the main magmatic channel and started to differentiate in isolation, generating the Lewolembwi and 1986 deposits and being remobilized during the

\section{8 eruption (see next section).}

Interactions between the main (trachy-basaltic) and peripheral (trachy-andesitic to trachydacitic) magma chambers must have also occurred prior to the 2018 eruption as evidenced by the presence of diffusion profiles in some olivines that record timescales in the order of years at the very minimum (i.e. could be decades or hundreds of years the profiles were not complete enough to calculate diffusion timescales). Trace element variations also suggest that chemical mixing might have played a role in the resulting compositions and the presence of frequent oscillatory zoning within the clinopyroxene phenocrysts might be further evidence of episodic mafic input into the more evolved magmatic reservoir. How much episodic chemical mixing

586 has occurred between these two components over the years is unknow. Also unknow is how much such interactions have contributed to past eruptions at Ambrym. 


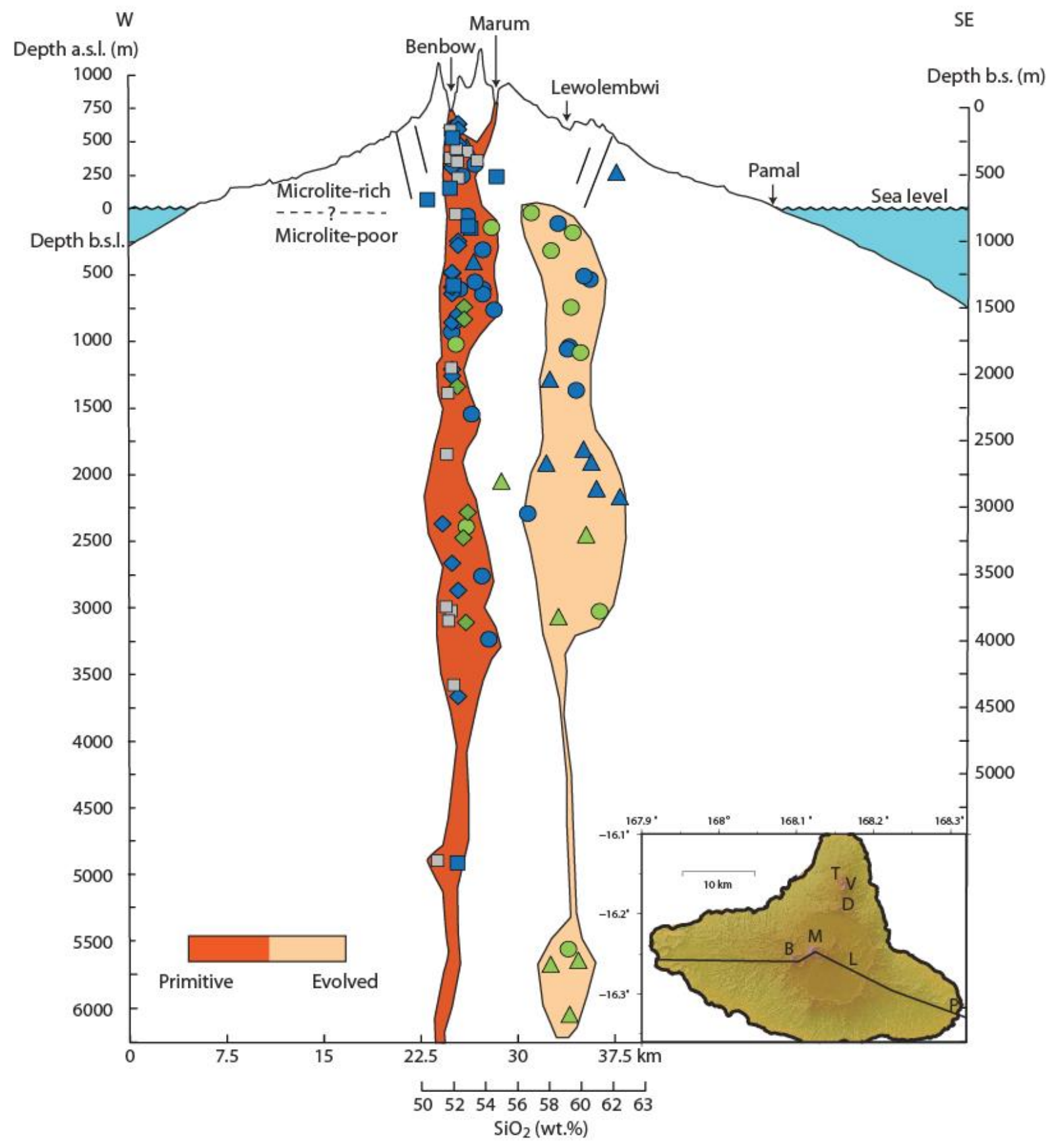

590 Fig. 10 Schematic cross-section representing the Ambrym plumbing system on which melt 591 inclusions entrapment pressure and $\mathrm{SiO}_{2}$ content are superimposed (with no implied relation 592 between $\mathrm{SiO}_{2}$ content and horizontal coordinates of the melt). Inset DEM shows the location 593 of the in-land part of the transect used to draw the elevation profile. The more mafic (dark 594 orange) and more silicic (light beige) magma chambers are drawn conceptually, their vertical 595 extent is constrained by MI entrapment pressures and pyroxene barometry, but their horizontal extent is unconstrained. We hypothesise that the more mafic magma is located underneath the Benbow and Marum crater as this is the composition that has feed all known eruptive activity at these craters while we envision that the more silicic magma is located underneath the Lewolembwi crater as magma of the same composition as our evolved end-member, make up

600 the Tuff ring forming this crater and the 1986 flow directly north of it (Robin et al. 1991; 601 Picard et al. 1994). The upper, degassed part of the mafic system is composed of microlite-rich 
602 magma, while the deeper part of the system is microlite-poor, the exact depth level separating

603 the two is unconstrained

604

605 Triggers and timing of the 2018 Ambrym eruption

606 Evidence of magma mingling during the 2018 Ambrym eruption are extremely clear, both in

607 the intra-caldera and in the submarine eruptions. Magma mingling can be seen at the micron to

608 millimetre scale in both deposits (Fig. 2). Chemical mixing is evidenced mostly in the

609 composition of the matrix glasses marginally bridging the trachy-basaltic and trachy-andesitic

610 to trachy-dacitic end member compositions (keeping in mind that these could partially also be

611 reflecting mingling at a very small scale) while the melt inclusion compositions mostly record

612 these two end members but show a clear compositional gap in between at $\mathrm{SiO}_{2}$ contents

613 between $\sim 55$ and $\sim 57$ wt.\% (Fig. 3). These evidence all suggest, to a first order, that encounter

614 of the two magmas occurred for a relatively short time prior to eruption given that mingling

615 textures are preserved and chemical mixing between the two end members is incomplete. This

616 is confirmed quantitatively by the modelling of diffusion profiles in olivine crystals from the

617 evolved components brought in contact with the more mafic component at calculated

618 timescales of hours to a few days prior to eruption. While it is clear that the encounter of these

619 two magmas played an important part in this eruption the real "trigger" is the event that brought

620 the main branch of the plumbing system (trachy-basalt) in contact with the previously isolated

621 and more differentiated eastern branch (trachy-andesite to trachy-dacite). In the following

622 discussion we combine our petrological findings with visual and geophysical observations to

623 constrain the nature and timing of the processes that occurred during the 2018 eruption.

624

625

1. An over pressurizing magmatic system

626 In the two weeks directly preceding the eruption the height of the main lava lake at Marum

627 crater increased rapidly with a rise in the lake level of $\sim 60 \mathrm{~m}$ between 30 November and 14 
628 December 2018 (Fig. S1). This increase in lake level likely indicates increased pressurization

629 of the magmatic system around that time.

630

631

2. First diking event, magma mixing, lava lake drainage and intra-caldera eruption.

632 Fe-Mg and Mn diffusion modelling from an olivine crystal erupted between 14 December at 633 23:20 and 15 December at 00:01 UTC at Lewolembwi crater records diffusion timescales < 634 10h, indicating than magma mixing was initiated within 10h of eruption (i.e. in the afternoon 635 of the 14 December 2018). This should be taken as an order of magnitude estimate being based 636 on a single diffusion profile. Geodetic modelling by Shreve et al., (2019) based on inversion 637 of InSAR interferogram for images covering the November 3 to December 15, 00:24 interval 638 identified the emplacement of a shallow dike with $2 \mathrm{~m}$ maximum opening (Fig.11). While the 639 exact timing of this dike emplacement cannot be resolved by InSAR, we suggest that this dyking event likely put in contact the two previously disconnected branches of the Ambrym

641 plumbing system with primitive magma from the main branch intersecting evolved magma 642 from the eastern branch and rising together to erupt at the surface. The intersection of the two 643 magma bodies probably occurred at shallow, 1 to $2.5 \mathrm{~km}$ depth (according to dike geodetic 644 modelling), draining the top $1 \mathrm{~km}$ portion of the main magmatic branch (as evidenced by the 645 abundance of magma from the top $1 \mathrm{~km}$ in the intra-caldera eruption and lack of any such 646 magma in the subsequent submarine eruption) (Fig. 11), causing the disappearance of the five 647 lava lakes and partial collapse of the Marum and Benbow craters. Magma ascent from $\sim 2.5 \mathrm{~km}$ 648 depth to the surface took less than 1 minute for magma ascending directly but was slower for 649 magma experiencing more complex history such as descending and laterally migrating prior to 650 eruption. 
$653 \mathrm{Fe}-\mathrm{Mg}, \mathrm{Mn}, \mathrm{Ni}$ and $\mathrm{Ca}$ diffusion modelling from three olivine crystals erupted during the

654 submarine eruption are all consistent with diffusion timescales $<2$ days. The estimated start of

655 the submarine eruption is at 16:00 on 17 December, based on abrupt decrease of seismic

656 moment release (Shreve et al., 2019). Magma mixing was therefore initiated sometime between

657 the 15 December evening and the 17 December (Fig. 7). This corresponds to a period of intense

658 seismic activity and surface deformation starting with a Mw 5.6 strike-slip earthquake on 15

659 December at $20 \mathrm{~h} 21$ and interpreted from geodetic modelling as the lateral, eastward

660 propagation of a dike with $\sim 3$ m of opening along $>30 \mathrm{~km}$ distance (Fig. 11) (Shreve et al.,

661 based on inversion of InSAR interferogram for images covering the 15 to 18 December period).

662 Magma mixing and dike propagation are therefore synchronous, and it seems likely that both

663 magma type became entrained in the same dike where mixing occurred. The tip of the dike

664 however was likely composed solely of the "main branch", more primitive magma as the very

665 first scoria that reached the island shore showed no indication of mixing and are all of basaltic

666 trachy-andesite to basaltic-andesite composition (Fig. 3). One caveat to consider however is

667 that while the start date of the submarine eruption is well estimated, we do not have an exact

668 date or time on the moment at which our scoria samples were erupted. The eruption might have

669 continued for up to two months (Shreve et al., 2019). Our diffusion timescales might hence not

670 be directly comparable to seismic events preceding the eruption initiation, but they still indicate

671 timescales of magma mixing with $<2$ days of mixing prior to eruption. While lateral magma

672 transport might have taken up to two days, vertical ascent from $\sim 4 \mathrm{~km}$ to the submarine eruption

673 site took just a minute, ascending at an average speed of $\sim 80 \mathrm{~km} / \mathrm{h}$.

674 

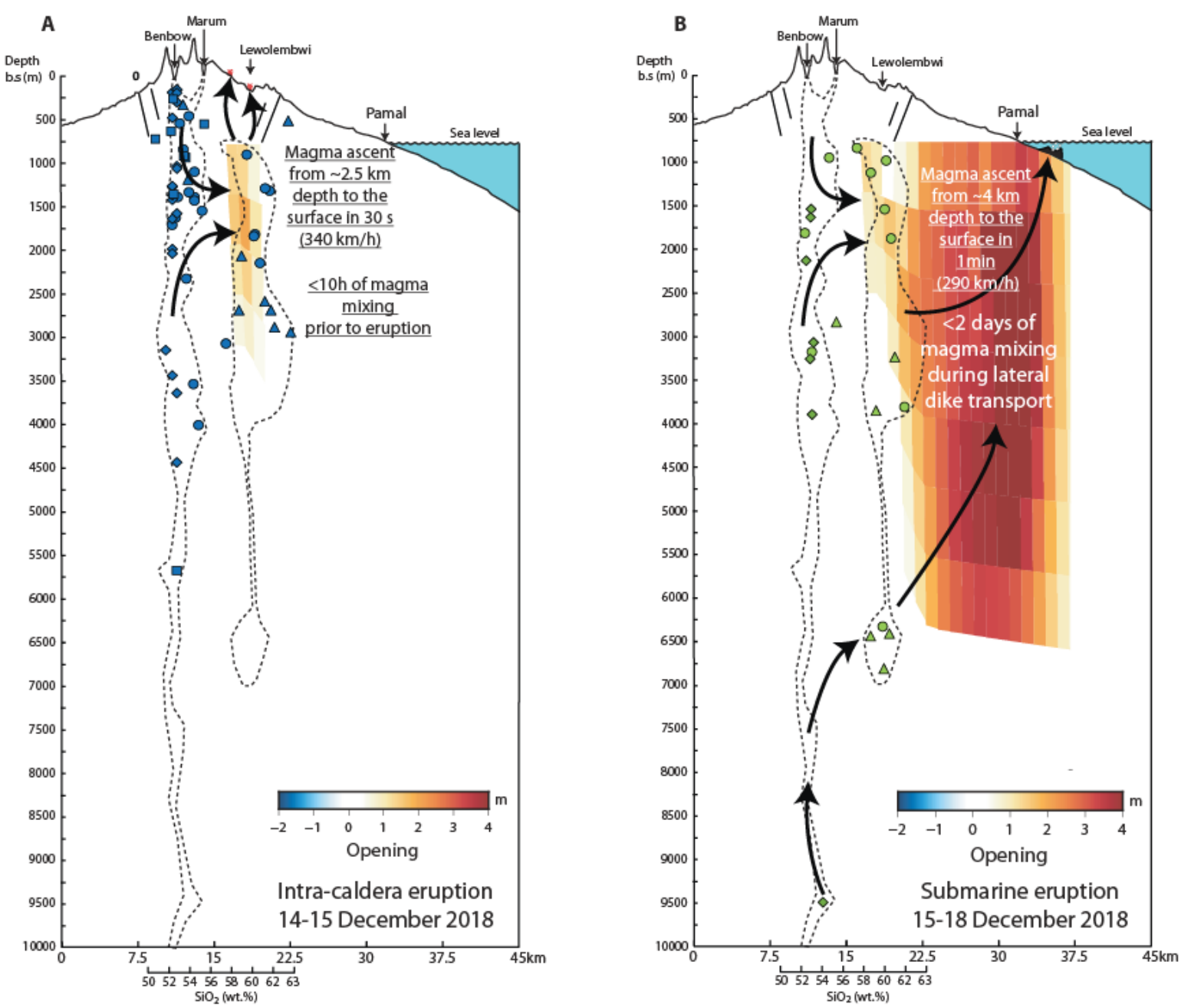

677 Fig. 11 Schematic cross-section of Ambrym volcano comparing the entrapment pressure of 678 melt inclusions erupted during $(\boldsymbol{A})$ the intra-caldera eruption and $(\boldsymbol{B})$ the submarine eruption 679 with the depth of diking events in the period $(\boldsymbol{A})$ November 3 to December 15 at 00:24 and (B) 680 December 15 to 18 (geodetic models from Shreve et al., 2019). Dotted lines represent the 681 hypothesized locations of the primitive and evolved magmatic branches (see Fig. 10 caption 682 and text for details). Black arrows show the inferred directions of magma migration. In (A) the 683 upper $\sim 1 \mathrm{~km}$ of the main magmatic branch underneath Benbow and Marum is drained, mixes 684 with the eastern, evolved magmatic branch and erupted together at Lewolembwi (the 685 composition of the lava erupted synchronously between Lewolembwi and Marum is unknown). 686 In (B) eastward magma migration might originate, or at least has a contribution from deeper 687 levels. Timescales of magma mixing and ascent rate from diffusion modelling of reverse 688 689 compositional zoning in olivine and volatile in melt embayments are reported for each eruption 


\section{Comparison with other lava-lake-draining rift eruptions}

692 If we look in detail at the last three eruptions that terminated or partially drained lava lakes at 693 basaltic volcanoes along a rift axis (2017-2020 Erta 'Ale, 2018 Kīlauea and 2018 Ambrym), 694 clear patterns seem to emerge. First, they all seem to be preceded by high levels of their lava 695 lake. At Kîlauea, the 2018 eruption was preceded by a high level of the lava lake at the summit 696 crater and a rising lava pond at $\mathrm{Pu}^{‘} \mathrm{u}^{`} \mathrm{O}^{`} \overline{\mathrm{o}}$ (Neal et al. 2019). At Erta 'Ale the lake level had 697 been rising (yet not constantly) since 2000 (Barnie et al. 2016), overflowing its bank directly 698 prior to the 2017 fissure eruption (Global Volcanism Program, 2017). As seen previously, at

699 Ambrym the lake level rose rapidly in the weeks prior to eruption (Fig. S1). Another, older 700 example is the 1977 lake-draining fissure eruption of Nyiragongo Volcano, which was preceded by a rise in the lake level of $200 \mathrm{~m}$ from 1959 to 1976 (Tazieff 1977). An inescapable conclusion seems to be that pressure build up in the magmatic system (as tracked by rising lava lake level), always precedes this type of eruption.

In all these examples, lake drainage (or subsidence) is then synchronous with magma migration and lateral fissure eruptions (Tazieff 1977; Moore et al. 2019; Neal et al. 2019; Shreve et al. 2019). This phenomenon was (to our knowledge) first documented at Kîlauea volcano in 1924 where drainage of the hundred-year-long lava lake accompanied an intrusion in the eastern rift zone (Jaggar and Finch 1924) and has since been documented extensively at Kîlauea (see review by Patrick et al. 2019). Yet another example is the 1913 eruption of Ambrym which had a remarkably similar pattern to the 2018 eruption. In 1913, the eruption began with a fissure eruption inside the caldera followed by magma migration along the rift axis (to the west) and magma eruption near the shoreline (Németh and Cronin 2011). Although it is not known how

714 the lava lake level responded at that time, Németh and Cronin (2008)'s investigation of 
715 Marum's crater walls revealed that episodes of lava lake pounding and subsequent drainage to

716 feed flank eruptions and excavation of the crater by associated phreatic to phreatomagmatic

717 eruptions has been a common occurrence throughout the volcano's history. Lake drainage

718 through dike migration and flank eruption is hence probably as recurrent a phenomenon at

719 Ambrym as it is at Kîlauea.

720

721 A peculiarity of the 2018 Ambrym eruption is the extrusion of evolved lava together with lava

722 of the same composition as the lava lakes. As seen in the previous section, it appears that a dike

723 propagating from the main magmatic branch intersected and remobilised evolved magma from

724 a peripheric magma chamber. Interestingly the same phenomenon seems to have occur during

725 the 2018 Kîlauea eruption during which an evolved (andesitic) peripheral magmatic pocket

726 was intersected by the main dike and remobilised during the eruption (although in the Kîlauea

727 case this occurred significantly further down-rift from the main system, Gansecki et al. 2019).

728 The presence of such isolated, differentiated and still eruptible magmatic branches at the

729 periphery of main magmatic systems might therefore be a more common occurrence than

730 previously realised. 


\section{CONCLUSIONS}

732 The 2018 Ambrym eruption, whilst volumetrically mostly occurring underground, was

733

734

735 spectacular. It drained five active lava lakes, caused partial collapse of their crater accompanied with large, possibly phreatic, explosions, a $2 \mathrm{~m}$ subsidence of the $12 \mathrm{~km}$ diameter caldera, magma migration for $30 \mathrm{~km}$ horizontal distance and eruption of mingled and slightly chemically mixed magma at intra-caldera fissure eruptions and just off the SE coast as a shallow submarine eruption. Much like previous ones, this eruption highlighted the fact that whilst most population centres on Ambrym island are located at large distance from the main vents, those located along the rift axis will continue to be at risk and impacted by future eruptive events as magma migrates quickly to the shoreline. In this contribution we presented the results of major and volatile element analyses in bulk rocks, matrix glasses, melt inclusions, embayments, and minerals to shed light on the nature and timing of magmatic processes operating during this eruption. The main conclusions we draw from our findings are (1) The eruption began with the meeting, mingling and limited chemical mixing of trachy-basaltic magma from the main magmatic system with more evolved trachy-andesitic to trachy-dacitic magma from an older peripheral and previously cut-off branch. (2) In detail, the trachy-basaltic magma is itself composed of two mingled component, one microlite-poor and one microliterich, the second possibly reflecting degassing processes due to convection at shallow depth underneath the lava lakes. (3) The primitive and evolved magmatic branches interact periodically, with at least one interaction occurring more than a year prior to the 2018 eruption. (4) Magma mixing took place less than 10h prior to intra-caldera eruption and for about 2 days during magma transport in a $>30 \mathrm{~km}$ dike from the centre of the island to the coast prior to submarine eruption. Magma ascent from 2.5 and $4 \mathrm{~km}$ depth to the surface took place at rates in the order of $95 \pm 24$ to $80 \pm 6 \mathrm{~m} / \mathrm{s}$. (5) Comparison with other lava-lake-draining eruptions reveals that lake level rise - indicating pressurisation of the magmatic system - always 
756

757

758

759

760

761

762

763

764

765

766

767

768

769

770

771

772

773

774

775

776

777

778

779

780

781

782

783

784

785

786

787

788

789

precedes this type of eruption, highlighting the usefulness of this parameter for future

monitoring. Furthermore, the presence of peripheral, more evolved magma pockets, cut-off

from the main magmatic system but still mobilizable and eruptible could be a more common

occurrence than previously realised.

\section{REFERENCES}

Allard P, Aiuppa A, Bani P, et al (2016a) Prodigious emission rates and magma degassing budget of major, trace and radioactive volatile species from Ambrym basaltic volcano, Vanuatu island Arc. J Volcanol Geotherm Res 322:119-143. https://doi.org/10.1016/j.jvolgeores.2015.10.004

Allard P, Burton M, Sawyer G, Bani P (2016b) Degassing dynamics of basaltic lava lake at a top-ranking volatile emitter: Ambrym volcano, Vanuatu arc. Earth Planet Sci Lett 448:69-80. https://doi.org/10.1016/j.epsl.2016.05.014

Anderson AT, Brown GG (1993) $\mathrm{CO}_{2}$ contents and formation pressures of some Kilauean melt inclusions. Am Mineral 78:794-803

Barnie TD, Oppenheimer C, Pagli C (2016) Does the lava lake of Erta 'Ale volcano respond to regional magmatic and tectonic events? An investigation using Earth Observation data. Geol Soc Lond Spec Publ 420:181-208. https://doi.org/10.1144/SP420.15

Bouvier A-S, Métrich N, Deloule E (2008) Slab-Derived Fluids in the Magma Sources of St. Vincent (Lesser Antilles Arc): Volatile and Light Element Imprints. J Petrol 49:14271448. https://doi.org/10.1093/petrology/egn031

Burgi P-Y, Darrah TH, Tedesco D, Eymold WK (2014) Dynamics of the Mount Nyiragongo lava lake. J Geophys Res Solid Earth 119:2013JB010895. https://doi.org/10.1002/2013JB010895

Carn SA, Fioletov VE, McLinden CA, et al (2017) A decade of global volcanic SO2 emissions measured from space. Sci Rep 7:44095. https://doi.org/10.1038/srep44095

Chen Y, Provost A, Schiano P, Cluzel N (2011) The rate of water loss from olivine-hosted melt inclusions. Contrib Mineral Petrol 162:625-636. https://doi.org/10.1007/s00410-0110616-5

Danyushevsky LV (2001) The effect of small amounts of $\mathrm{H} 2 \mathrm{O}$ on crystallisation of mid-ocean ridge and backarc basin magmas. J Volcanol Geotherm Res 110:265-280. https://doi.org/10.1016/S0377-0273(01)00213-X

Danyushevsky LV, Plechov P (2011) Petrolog3: Integrated software for modeling crystallization processes. Geochem Geophys Geosystems 12:n/a-n/a. https://doi.org/10.1029/2011GC003516 
Ferguson DJ, Gonnermann HM, Ruprecht P, et al (2016) Magma decompression rates during explosive eruptions of Kîlauea volcano, Hawaii, recorded by melt embayments. Bull Volcanol 78:71. https://doi.org/10.1007/s00445-016-1064-X

Firth C, Handley H, Turner S, et al (2016) Variable Conditions of Magma Storage and Differentiation with Links to Eruption Style at Ambrym Volcano, Vanuatu. J Petrol 57:1049-1072. https://doi.org/10.1093/petrology/egw029

Gansecki C, Lee RL, Shea T, et al (2019) The tangled tale of Kîlauea's 2018 eruption as told by geochemical monitoring. Science 366:. https://doi.org/10.1126/science.aaz0147

Giachetti T, Druitt TH, Burgisser A, et al (2010) Bubble nucleation, growth and coalescence during the 1997 Vulcanian explosions of Soufrière Hills Volcano, Montserrat. J Volcanol Geotherm Res 193:215-231. https://doi.org/10.1016/j.jvolgeores.2010.04.001

Girona T, Costa F (2013) DIPRA: A user-friendly program to model multi-element diffusion in olivine with applications to timescales of magmatic processes. Geochem Geophys Geosystems 14:422-431. https://doi.org/10.1029/2012GC004427

Gorton MP (1977) The geochemistry and origin of quaternary volcanism in the New Hebrides. Geochim Cosmochim Acta 41:1257-1270. https://doi.org/10.1016/00167037(77)90071-0

Gurioli L, Colo' L, Bollasina AJ, et al (2014) Dynamics of Strombolian explosions: Inferences from field and laboratory studies of erupted bombs from Stromboli volcano. J Geophys Res Solid Earth 119:319-345. https://doi.org/10.1002/2013JB010355

Harris AJL (2008) Modeling lava lake heat loss, rheology, and convection. Geophys Res Lett 35:. https://doi.org/10.1029/2008GL033190

Harris AJL, Carniel R, Jones J (2005) Identification of variable convective regimes at Erta Ale Lava Lake. J Volcanol Geotherm Res 142:207-223. https://doi.org/10.1016/j.jvolgeores.2004.11.011

Hauri E, Wang J, Dixon JE, et al (2002) SIMS analysis of volatiles in silicate glasses: 1 . Calibration, matrix effects and comparisons with FTIR. Chem Geol 183:99-114. https://doi.org/10.1016/S0009-2541(01)00375-8

Iacono-Marziano G, Morizet Y, Le Trong E, Gaillard F (2012) New experimental data and semi-empirical parameterization of $\mathrm{H} 2 \mathrm{O}-\mathrm{CO} 2$ solubility in mafic melts. Geochim Cosmochim Acta 97:1-23. https://doi.org/10.1016/j.gca.2012.08.035

Jaggar TA, Finch RH (1924) The explosive eruption of Kilauea in Hawaii, 1924. Am J Sci Series 5 Vol. 8:353-374. https://doi.org/10.2475/ajs.s5-8.47.353

Kazahaya K, Shinohara H, Saito G (1994) Excessive degassing of Izu-Oshima volcano: magma convection in a conduit. Bull Volcanol 56:207-216. https://doi.org/10.1007/BF00279605

Kress VC, Carmichael ISE (1988) Stoichiometry of the iron oxidation reaction in silicate melts. Am Mineral 73:1267-1274 
Lange RL, Carmichael ISE (1990) Thermodynamic properties of silicate liquids with emphasis on density, thermal expansion and compressibility. Rev Mineral Geochem 24:25-64

Lautze NC, Houghton BF (2005) Physical mingling of magma and complex eruption dynamics in the shallow conduit at Stromboli volcano, Italy. Geology 33:425-428. https://doi.org/10.1130/G21325.1

Moore C, Wright T, Hooper A, Biggs J (2019) The 2017 Eruption of Erta 'Ale Volcano, Ethiopia: Insights Into the Shallow Axial Plumbing System of an Incipient Mid-Ocean Ridge. Geochem Geophys Geosystems 20:5727-5743. https://doi.org/10.1029/2019GC008692

Moussallam Y, Bani P, Curtis A, et al (2016) Sustaining persistent lava lakes: Observations from high-resolution gas measurements at Villarrica volcano, Chile. Earth Planet Sci Lett 454:237-247. https://doi.org/10.1016/j.eps1.2016.09.012

Moussallam Y, Oppenheimer C, Scaillet B, et al (2015a) Megacrystals track magma convection between reservoir and surface. Earth Planet Sci Lett 413:1-12. https://doi.org/10.1016/j.epsl.2014.12.022

Moussallam Y, Oppenheimer C, Scaillet B, et al (2015b) Megacrystals track magma convection between reservoir and surface. Earth Planet Sci Lett 413:1-12. https://doi.org/10.1016/j.eps1.2014.12.022

Moussallam Y, Rose-Koga EF, Koga KT, et al (2019) Fast ascent rate during the 2017-2018 Plinian eruption of Ambae (Aoba) volcano: a petrological investigation. Contrib Mineral Petrol 174:90. https://doi.org/10.1007/s00410-019-1625-z

Neal CA, Brantley SR, Antolik L, et al (2019) The 2018 rift eruption and summit collapse of Kīlauea Volcano. Science 363:367-374. https://doi.org/10.1126/science.aav7046

Németh K, Cronin SJ (2011) Drivers of explosivity and elevated hazard in basaltic fissure eruptions: The 1913 eruption of Ambrym Volcano, Vanuatu (SW-Pacific). J Volcanol Geotherm Res 201:194-209. https://doi.org/10.1016/j.jvolgeores.2010.12.007

Németh K, Cronin SJ (2008) Volcanic craters, pit craters and high-level magma-feeding systems of a mafic island-arc volcano: Ambrym, Vanuatu, South Pacific. Geol Soc Lond Spec Publ 302:87-102. https://doi.org/10.1144/SP302.6

Oppenheimer C, Lomakina AS, Kyle PR, et al (2009) Pulsatory magma supply to a phonolite lava lake. Earth Planet Sci Lett 284:392-398

Patrick M, Swanson D, Orr T (2019) A review of controls on lava lake level: insights from Halema'uma'u Crater, Kỉlauea Volcano. Bull Volcanol 81:13. https://doi.org/10.1007/s00445-019-1268-y

Picard C, Monzier M, Eissen J-P, Robin C (1994) Concomitant evolution of tectonic environment and magma geochemistry, Ambrym volcano (Vanuatu, New Hebrides arc). Geol Soc Lond Spec Publ 81:135-154. https://doi.org/10.1144/GSL.SP.1994.081.01.08 
867

868

869

870

871

872

873

874

875

876

877

878

879

880

881

882

883

884

885

886

887

888

889

890

891

892

893

894

895

896

897

898

899

900

901

902

903

904

905

Pichavant M, Carlo ID, Rotolo SG, et al (2013) Generation of CO2-rich melts during basalt magma ascent and degassing. Contrib Mineral Petrol 166:545-561. https://doi.org/10.1007/s00410-013-0890-5

Robin C, Monzier M, Eissen J-P, et al (1991) Coexistence de lignées HK et MK dans les pyroclastites associées à la caldera d'Ambrym (Vanuatu - Arc des NouvellesHébrides). Comptes Rendus Académie Sci 2 Mécanique 313:1425-1432

Rose-Koga EF, Koga KT, Devidal J-L, et al (2020) In-situ measurements of magmatic volatile elements, F, S, and $\mathrm{Cl}$, by electron microprobe, secondary ion mass spectrometry, and heavy ion elastic recoil detection analysis. Am Mineral 105:616-626. https://doi.org/10.2138/am-2020-7221

Rose-Koga EF, Koga KT, Hamada M, et al (2014) Volatile (F and Cl) concentrations in Iwate olivine-hosted melt inclusions indicating low-temperature subduction. Earth Planets Space 66:81. https://doi.org/10.1186/1880-5981-66-81

Schiano P, Monzier M, Eissen J-P, et al (2010) Simple mixing as the major control of the evolution of volcanic suites in the Ecuadorian Andes. Contrib Mineral Petrol 160:297312. https://doi.org/10.1007/s00410-009-0478-2

Sheehan F, Barclay J (2016) Staged storage and magma convection at Ambrym volcano, Vanuatu. J Volcanol Geotherm Res 322:144-157. https://doi.org/10.1016/j.jvolgeores.2016.02.024

Shimizu K, Shimizu N, Komiya T, et al (2009) CO2-rich komatiitic melt inclusions in Crspinels within beach sand from Gorgona Island, Colombia. Earth Planet Sci Lett 288:33-43. https://doi.org/10.1016/j.eps1.2009.09.005

Shishkina TA, Botcharnikov RE, Holtz F, et al (2014) Compositional and pressure effects on the solubility of $\mathrm{H} 2 \mathrm{O}$ and $\mathrm{CO} 2$ in mafic melts. Chem Geol 388:112-129. https://doi.org/10.1016/j.chemgeo.2014.09.001

Shreve T, Grandin R, Boichu M, et al (2019) From prodigious volcanic degassing to caldera subsidence and quiescence at Ambrym (Vanuatu): the influence of regional tectonics. Sci Rep 9:1-13. https://doi.org/10.1038/s41598-019-55141-7

Smythe DJ, Wood BJ, Kiseeva ES (2017) The S content of silicate melts at sulfide saturation: New experiments and a model incorporating the effects of sulfide composition. Am Mineral 102:795-803. https://doi.org/10.2138/am-2017-5800CCBY

Tazieff H (1977) An exceptional eruption: Mt. Niragongo, Jan. 10th, 1977. Bull Volcanol 40:189-200. https://doi.org/10.1007/BF02596999

Tazieff H (1994) Permanent lava lakes: observed facts and induced mechanisms. J Volcanol Geotherm Res 63:3-11. https://doi.org/10.1016/0377-0273(94)90015-9

Toplis MJ (2005) The thermodynamics of iron and magnesium partitioning between olivine and liquid: criteria for assessing and predicting equilibrium in natural and experimental systems. Contrib Mineral Petrol 149:22-39. https://doi.org/10.1007/s00410-004-06294 
906 Toramaru A (2006) BND (bubble number density) decompression rate meter for explosive 907 volcanic eruptions. J Volcanol Geotherm Res 154:303-316. https://doi.org/10.1016/j.jvolgeores.2006.03.027

909 Witham F, Llewellin EW (2006) Stability of lava lakes. J Volcanol Geotherm Res 158:321-

\section{ACKNOWLEDGEMENTS}

913 This research was conducted as part of the Trail by Fire II - Closing the Ring project (PI: Y.

914 Moussallam) with support from National Geographic (grant number CP-122R-17) the Rolex Awards

915 for Enterprise and the French national Research Institute for Development (IRD). We thank

916 Nordine Bouden and Etienne Deloule of CRPG (France) for their precious guidance during

917 SIMS analysis. We thank Mhammed Benbakkar for ICP-AES analyses and Claire Fonquernie

918 for help with sample preparation. MB acknowledges support from the French National

919 Research Agency (ANR) for funding the VOLCPLUME project (ANR-15-CE04-0003-01).

920 We are grateful for the constructive reviews provided by Nicole Métrich and two anonymous

921 reviewers on an earlier version of this manuscript and to Nicole Métrich for editorial handling. 